$$
\begin{aligned}
& \text { علي سالم شهاب أحد } \\
& \text { الدكتور علاء احمد حسن الجبوري } \\
& \text { باحث -قسم إدارة الأعمال } \\
& \text { مدرس - قسم ادارة الاعمال } \\
& \text { كلية الإدارة والاقتصاد - جامعة الموصل }
\end{aligned}
$$

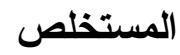

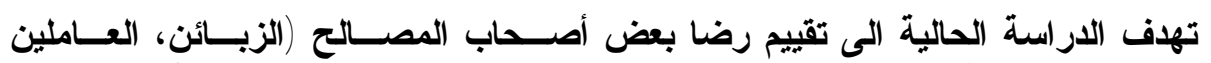

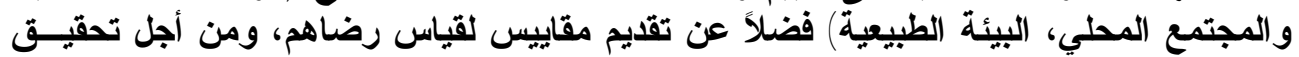

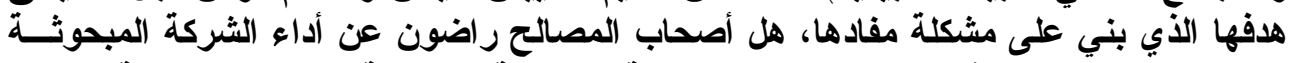

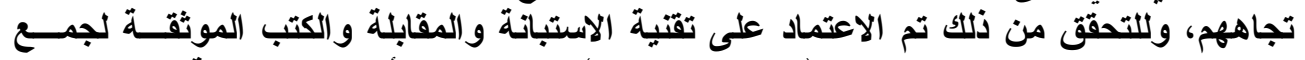

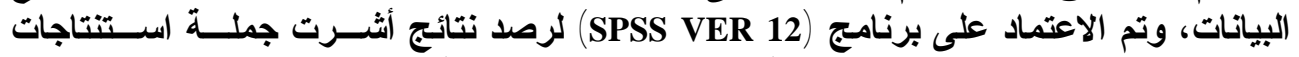

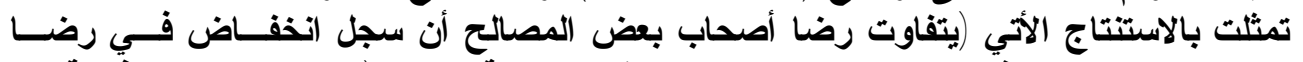

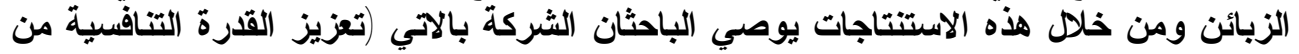

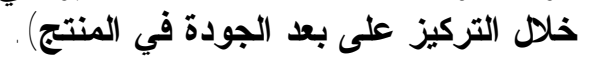
الكلمات المفتحبةٍِ 


\title{
Measurement the Satisfaction of Some Stakeholders: A Field Study in the General Company for the Pharmaceutical Industry in Nineveh
}

\author{
Alaa' Ahmad H. (PhD) \\ Lecturer \\ Department of Business Administration \\ University of Mosul \\ alaa_aaa_2006@yahoo.com
}

\section{Ali Salem al-Shihab Ahmad \\ Researcher}

Department of Business Administration

University of Mosul

\begin{abstract}
The study aimed to identify the satisfaction of some stakeholders (customers, employees and local community, natural environment), as well as measure their satisfaction. Due to achieve its goal, the problem is summarized in; have the stakeholders been diagnosed for the company researched. In order to verify that, the reliance on questionnaire technique and interview, textbooks, documents for the data collection, relied on a program (SPSS ver. 12) to observe the results. A group of results has been indicated in the variance of stakeholders' satisfaction, it also recorded low customer satisfaction. According to these results, it is necessary to recommend the following by the company (enhance the competitive advantage through focusing on the quality of product).
\end{abstract}

\section{Kew words:}

Customers, Employees, Community, Natural Environment

تعكس فاعلية أداء أي منظمة قدرتها على التعامل مع فئات مختلفة، يعبــر عنهـــا

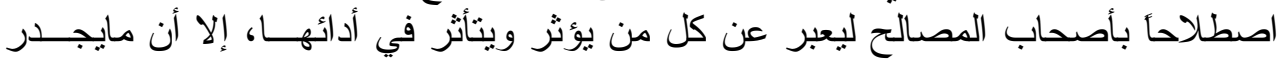

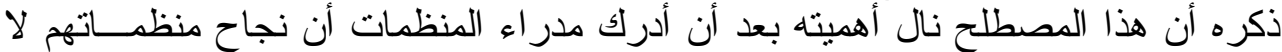
يعتمد على رضا زبائنها فقط، و إنما على فئات أخرى (العاملين، البيئة الطبيعية ونحو هما) بوصفهم نتيجة لتحقيق رضا الزبائن، وبهذا وجدنا إمكانية قياس رضا هذه الفئات بوصفها

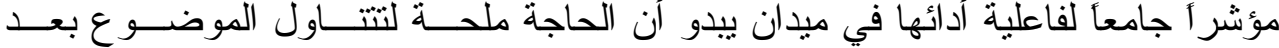

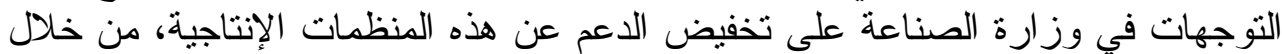
ما يعرف بالتحول نحو التمويل الذاتي، ومن أجل تحديد ما ذهبنا إلبه وفق منهجية تؤشــر

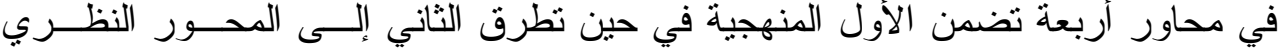
و الثالث تتاول الميداني وصو لا إلى الاستتناجات و التوصيات .

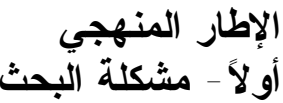

كثفت معطيات الدر اسة الاستطلاعية للثركة العامة لصناعة الأدوية و المستلزمات

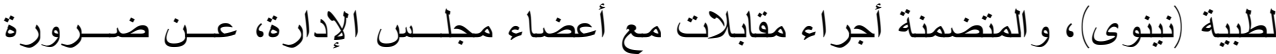




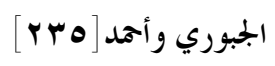

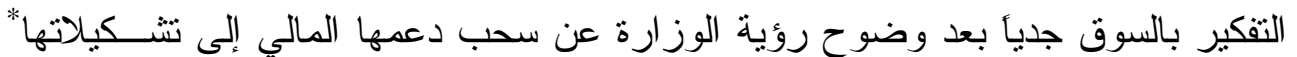

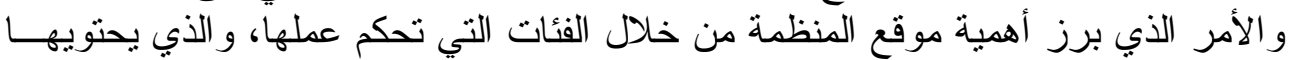

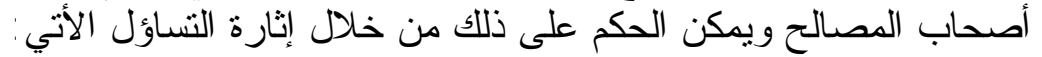

(هل هناك رضا من قبل الفئات الزبائن، العاملين، المجتمع المحلي، الجهات المنات المعنيــة

بالبيئة عن أداء الثركة المبحوثة)

تظهر أهمية الدر اسة من خلال الأهمية النظرية و الأهمية الميدانية:

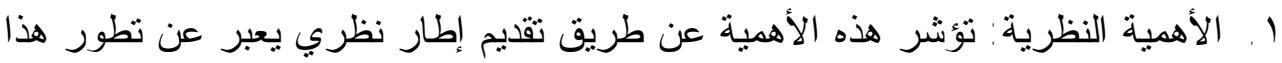

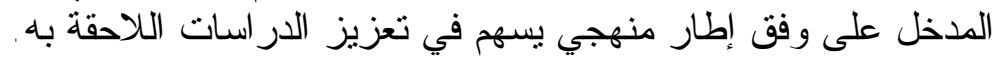

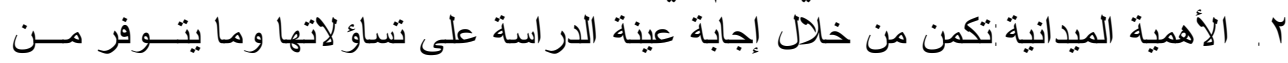

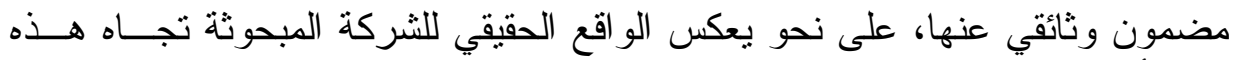

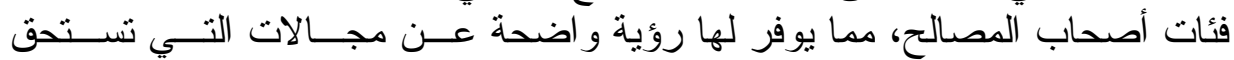

التعزيز بما يجعلها في الموقع المناسب لها.

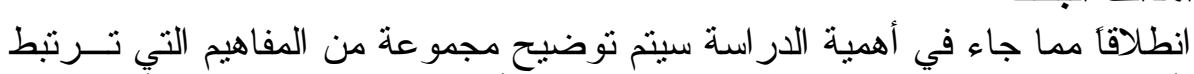

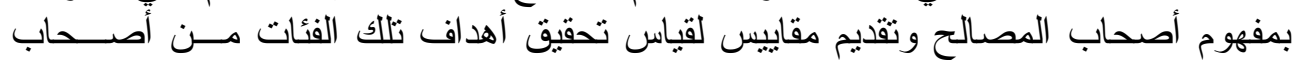

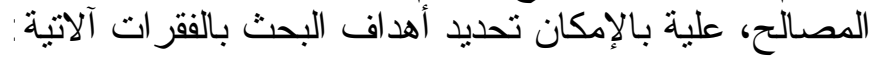

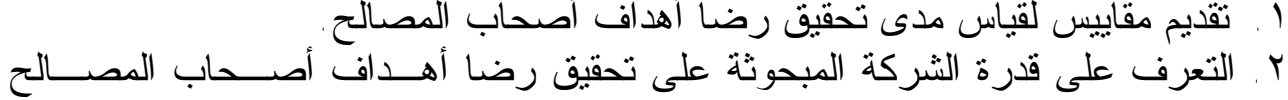

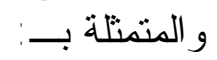

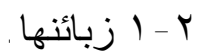

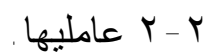

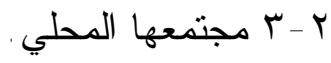

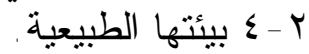

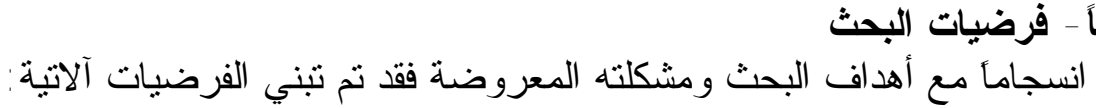

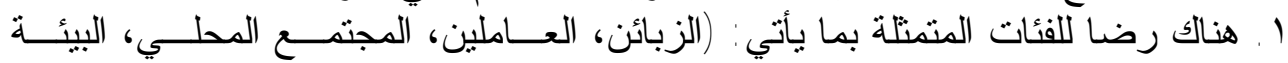

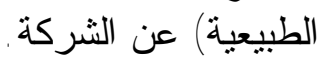

r ب يتفاوت رضا كل من الجهات: (الزبائن، العاملين، المجتمع المحلي، البيئــة الطبيعيـة)

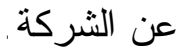

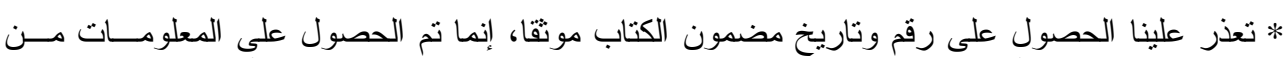

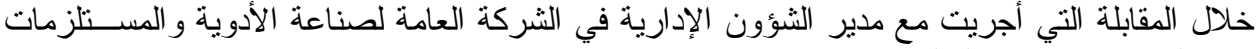

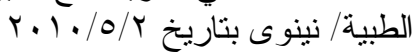




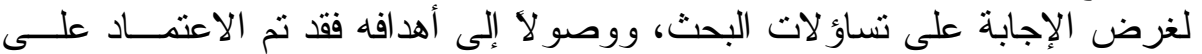

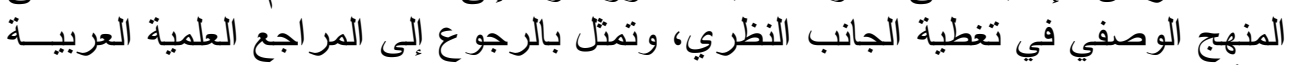

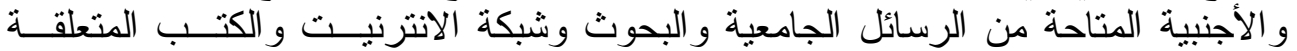

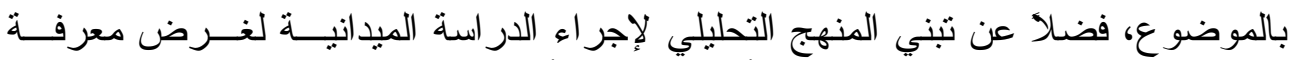

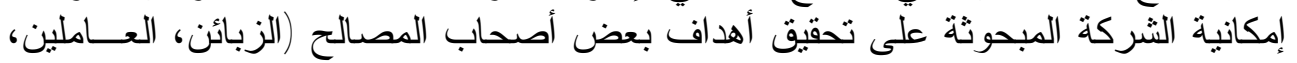
المجتمع المحلي، البيئة الطبيعية) .

\section{سادساً - حدود البحث الزمانية و المكانية ومجتمعه وعينته}

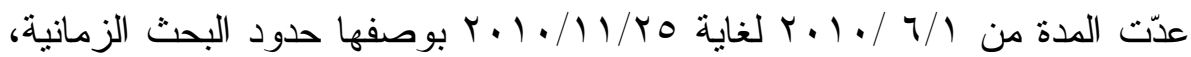

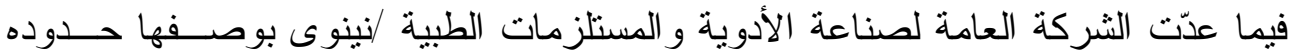

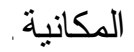
أما فيما يخص مجتمع البحث، فبلغ (9 ـ ( ) منتسب، وهم يشكلون جملة العاملين في سبعة اقسام للشركة.

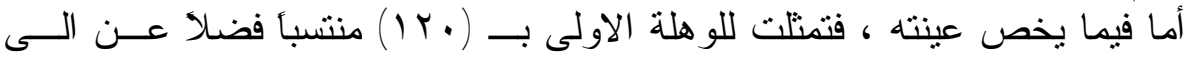

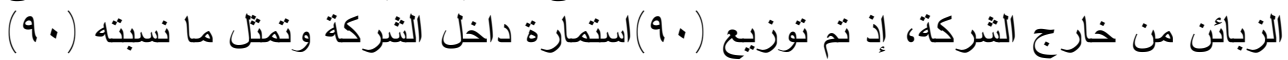

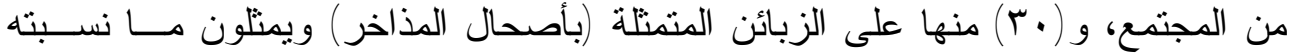

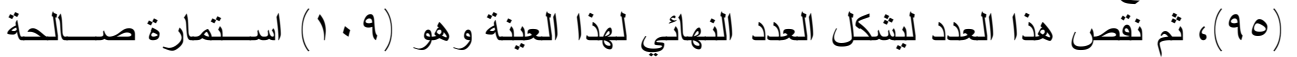

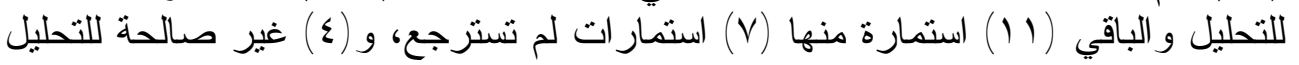

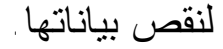

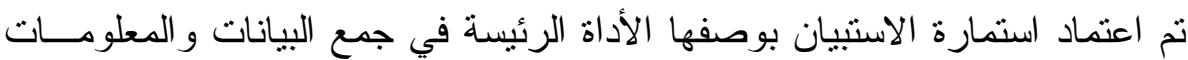

سابعاً - أداة البحث وثثباتها

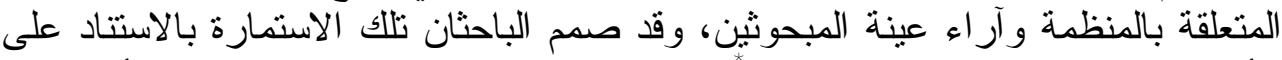

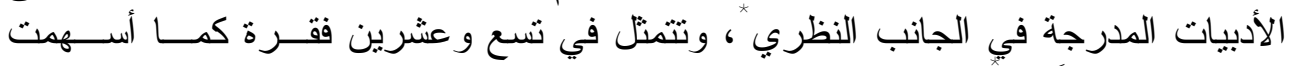

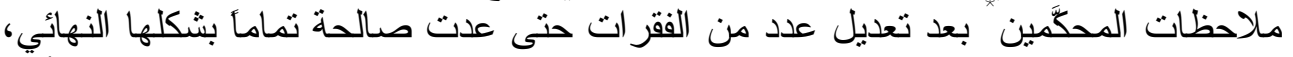

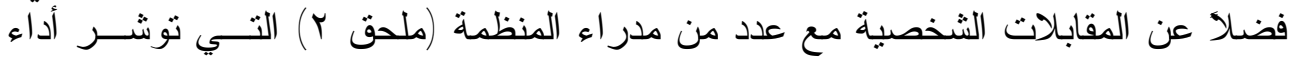

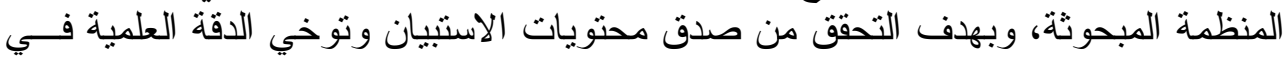

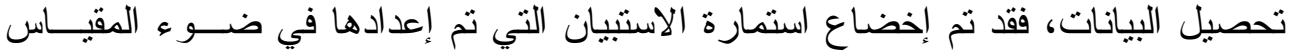

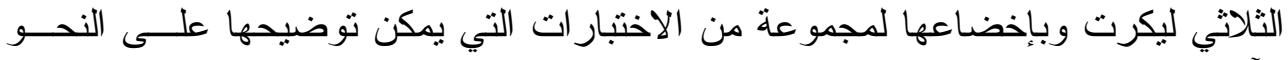

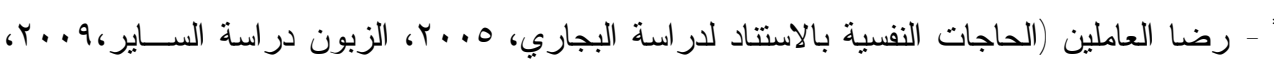

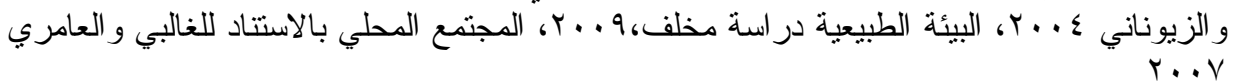

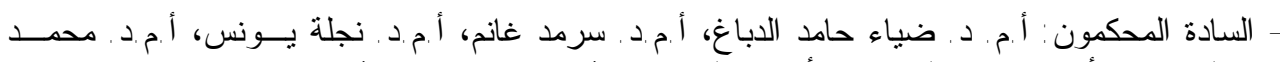

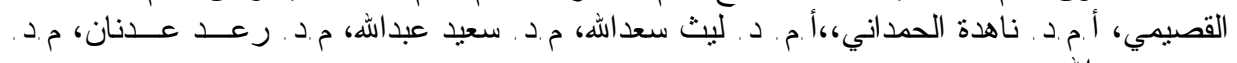




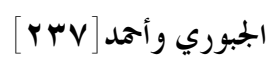

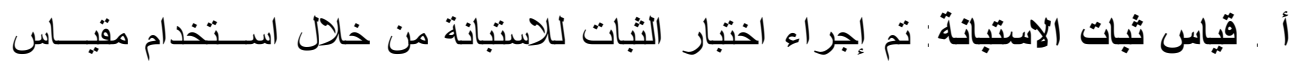

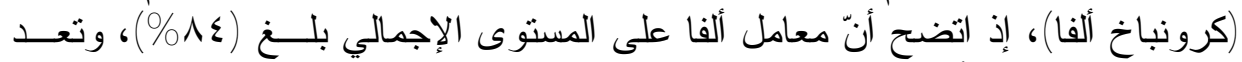

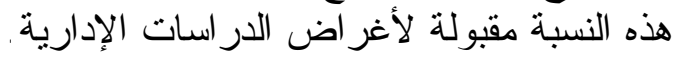

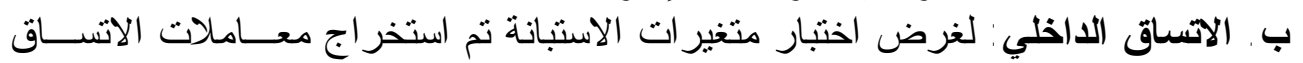

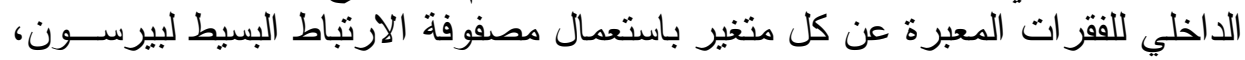

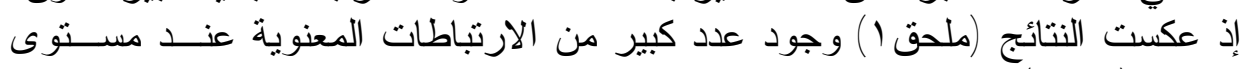

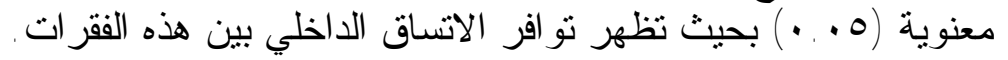

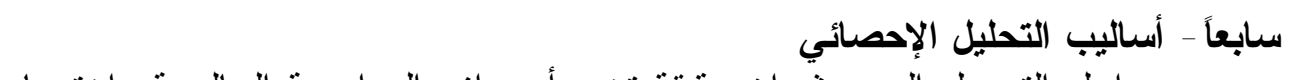

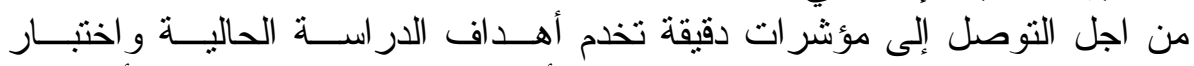

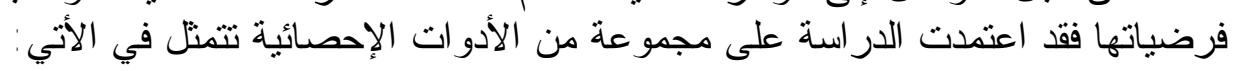

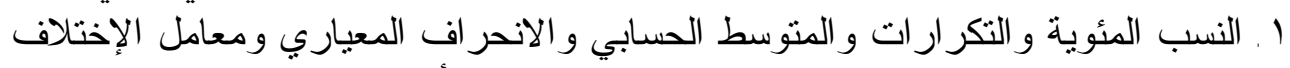

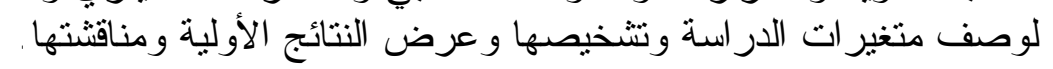

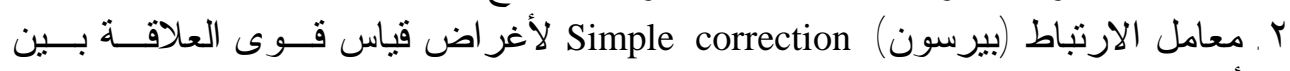

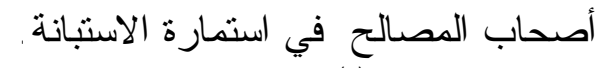

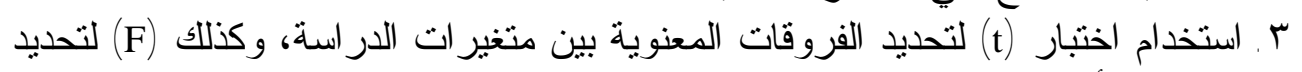

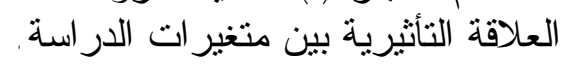

\section{الإطار النظري \\ أولاًا - التطور التظري التخي لمفهوم أصحاب المصالح}

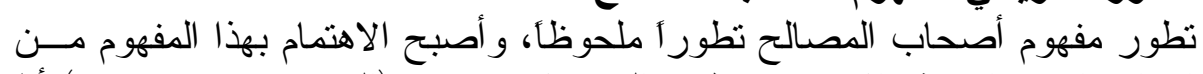

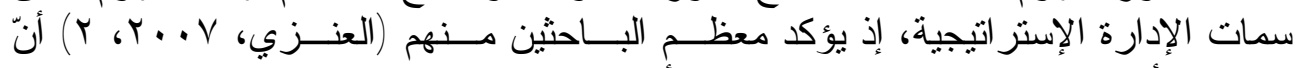

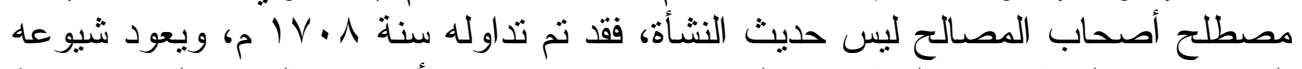

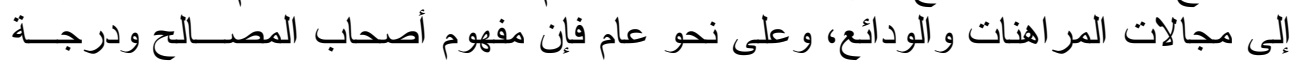

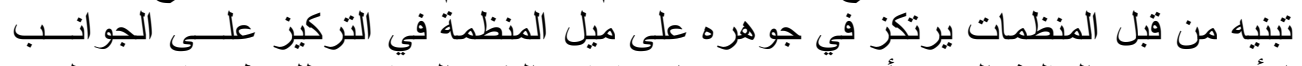

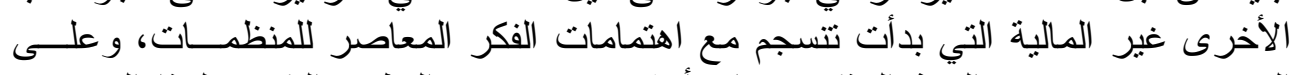

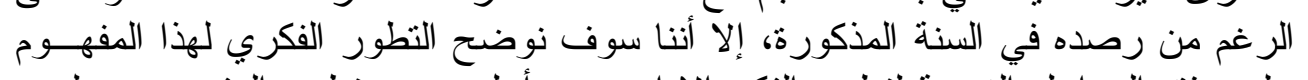

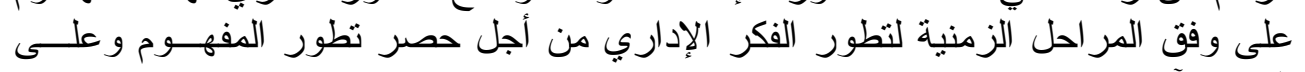

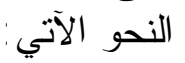

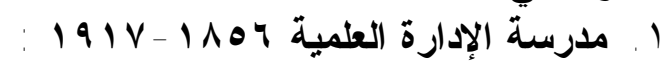

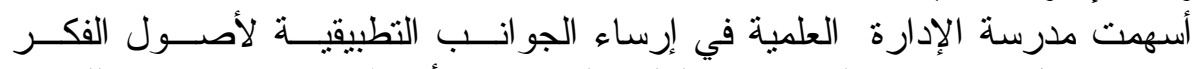

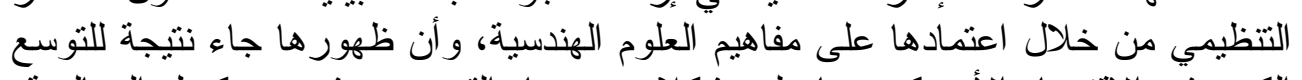

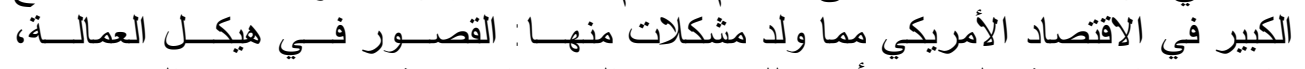

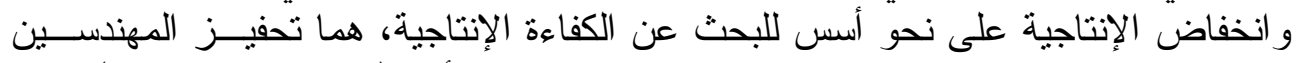

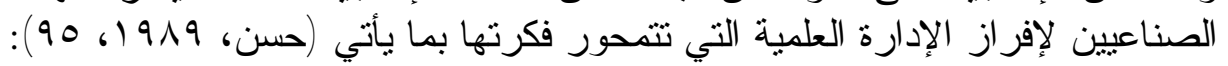

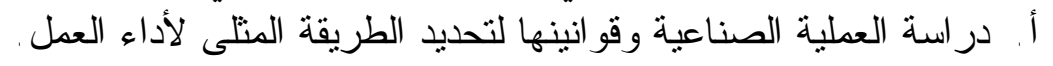

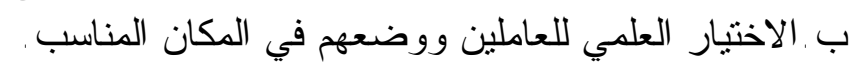

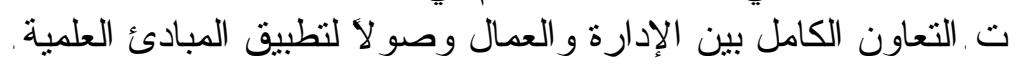
ث .تقسيم العمل و المسؤولية بين الإدارة و العمال ( التخطيط للإدارة و التنفيذ للعمال) . 


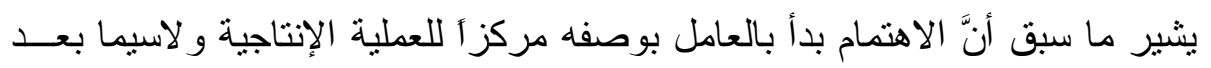

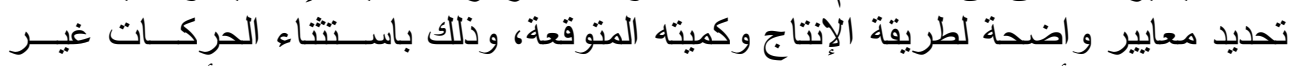

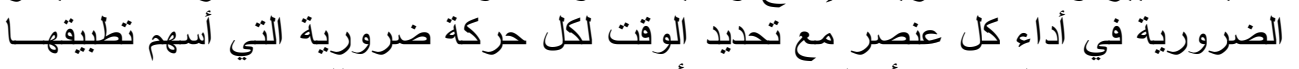

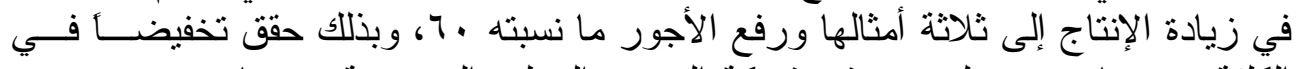

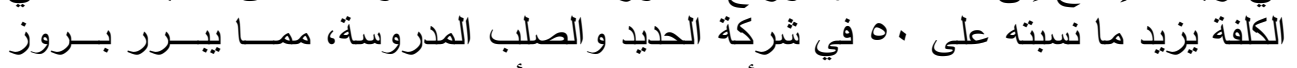

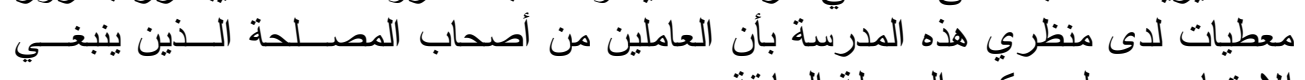

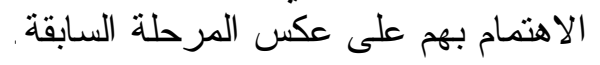

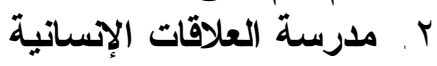

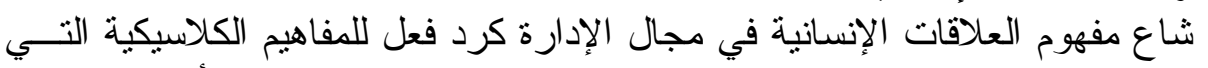

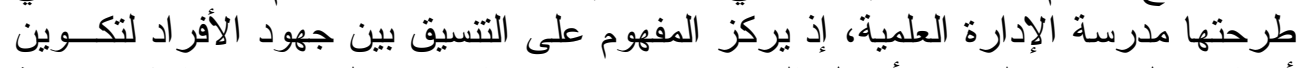

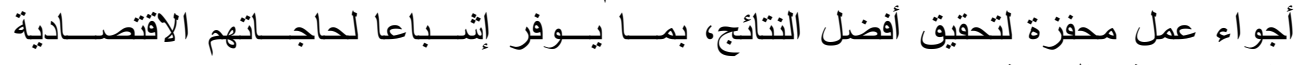
و الاجتماعية و النفسية.

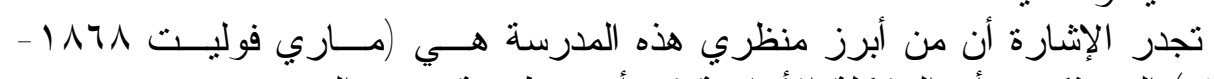

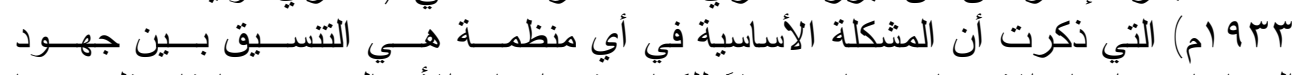

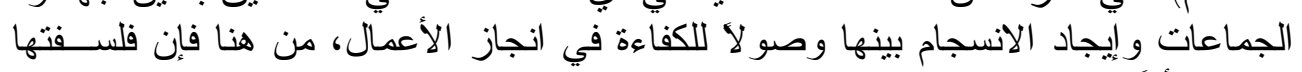

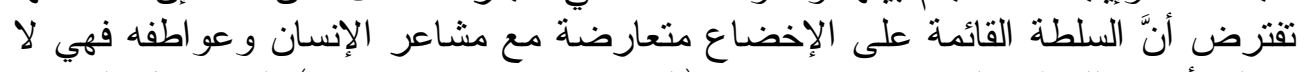

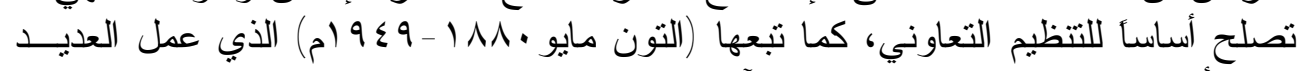

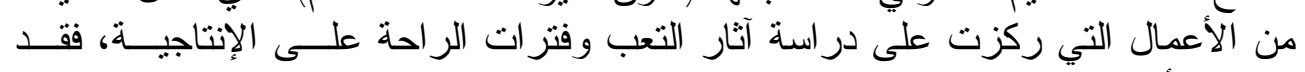

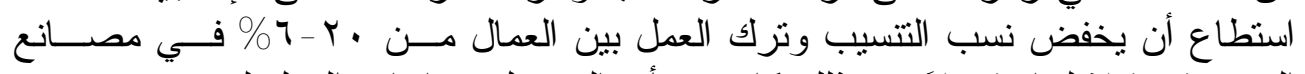

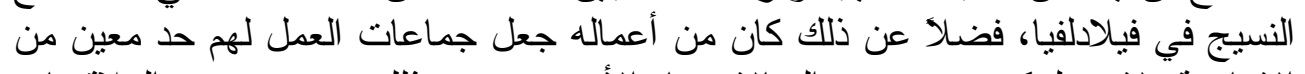

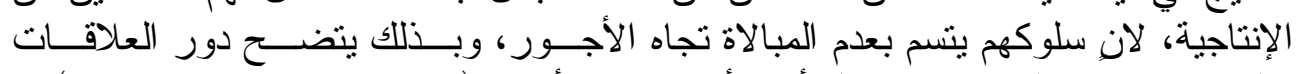

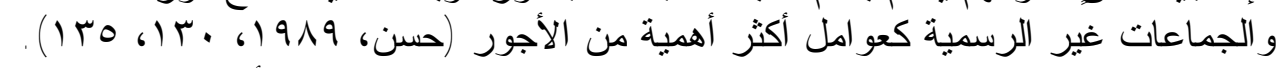

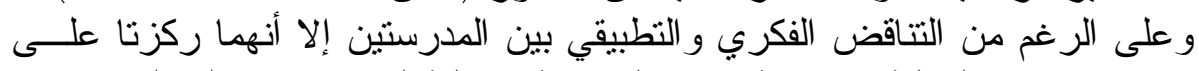

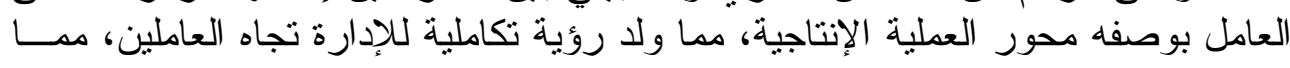
عزز دوره كصاحب مصلحة في المنظمة الإنة r. مرحلة حملة الأسهر والهيئت المدئية

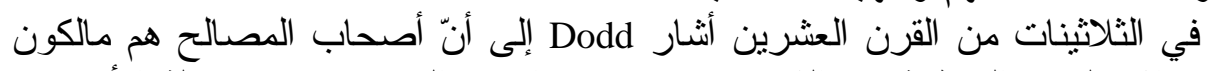

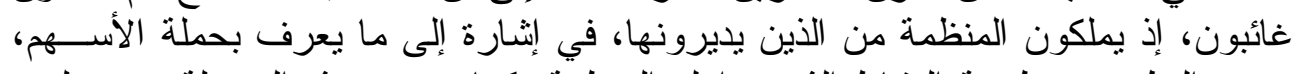

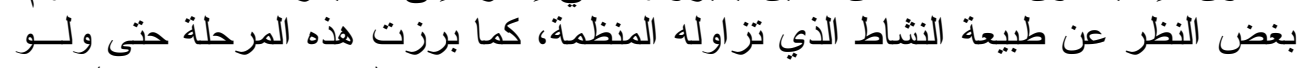

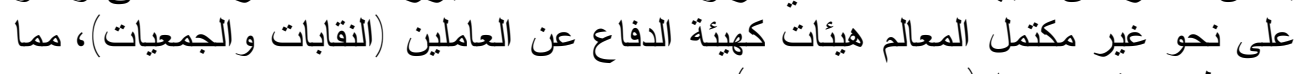
برز ظهور فئتين هما (Johes, 2001,2): 1. 1. الذين لهم مصالح مالية.

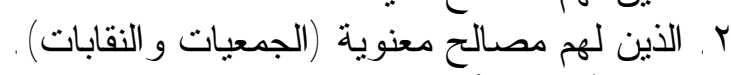
ع ـ ـ مرحة بروز أصحاب المصالح

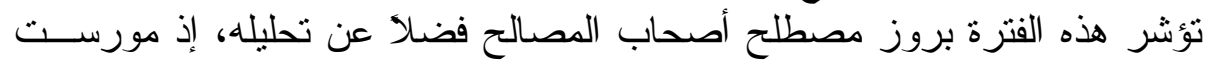

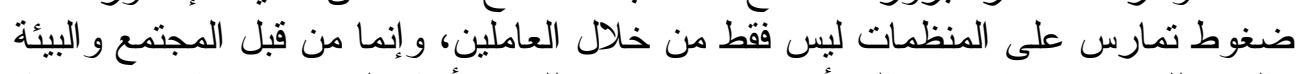

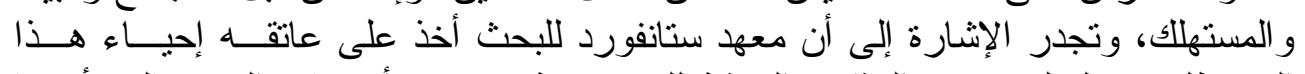

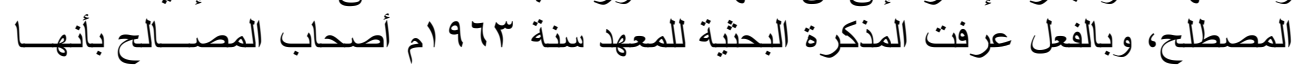




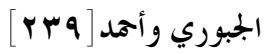

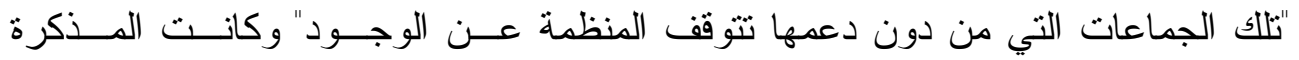

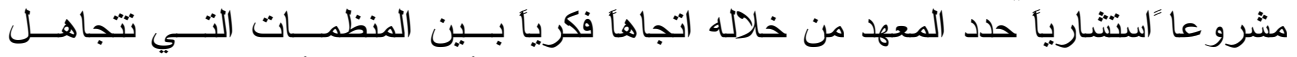

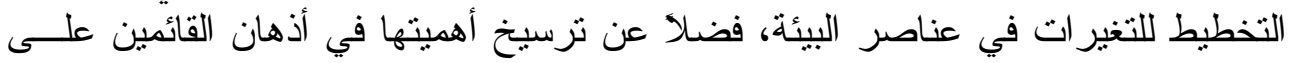

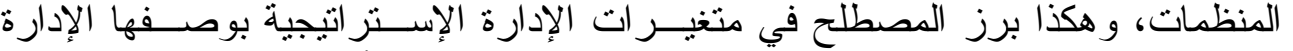

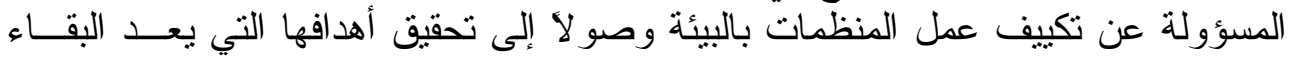

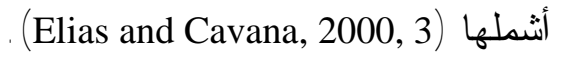

ه. مرحلة النضج في الإدارة الإستر اتيجية

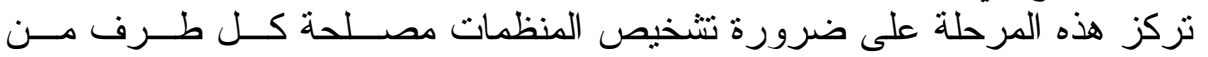

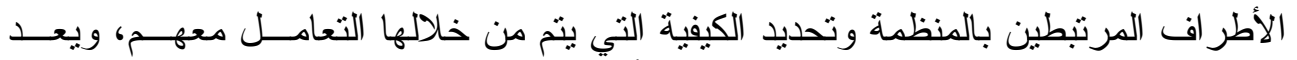
Freeman

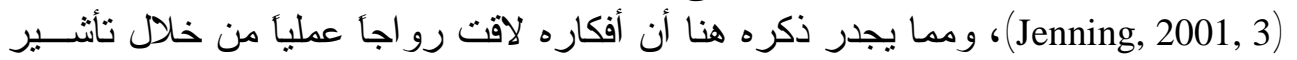

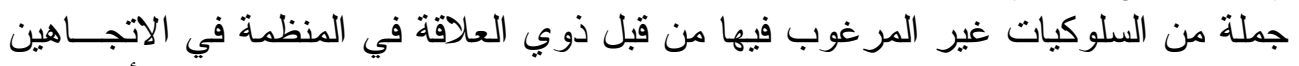

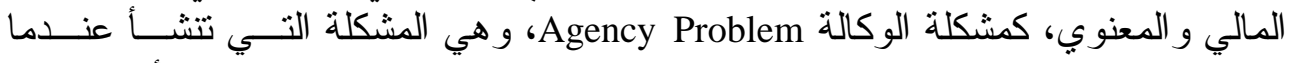

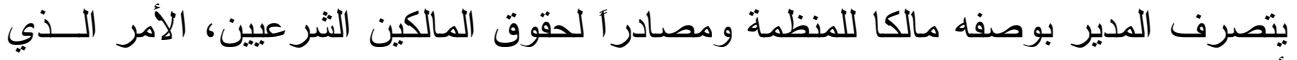

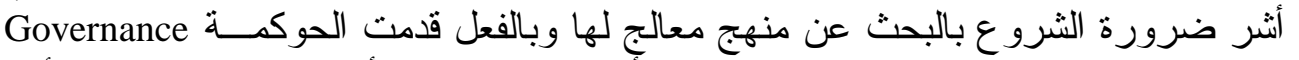

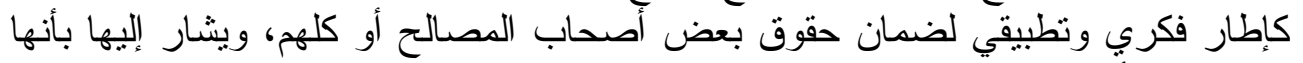

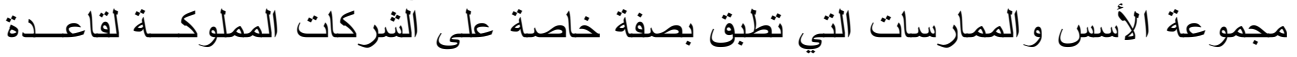

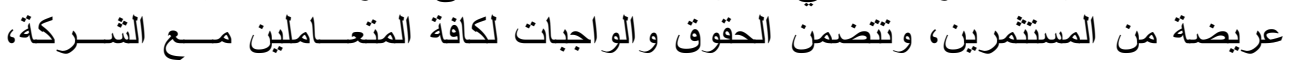

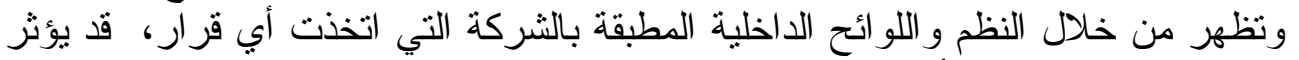

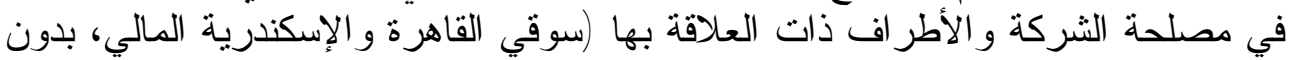

ثانياً - مفهوم أصحاب المصالح ودواعي الاهتمام به

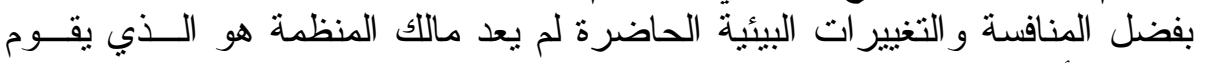

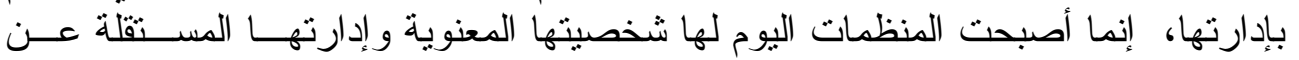

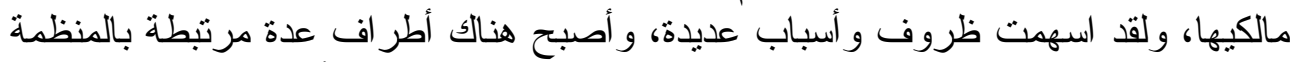

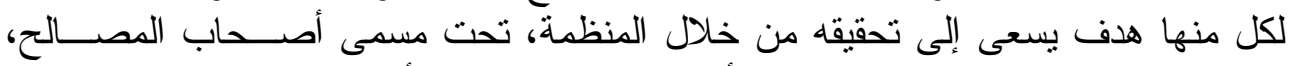

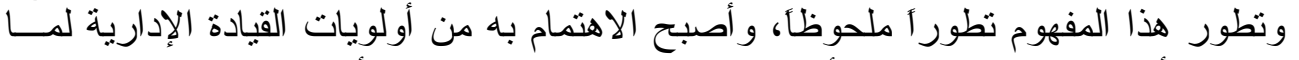

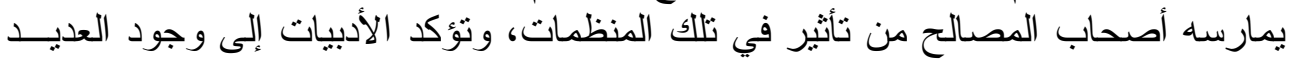

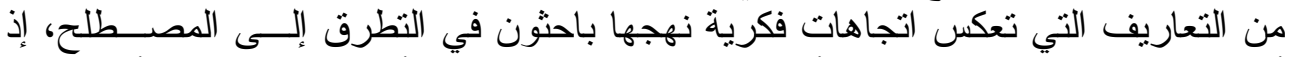

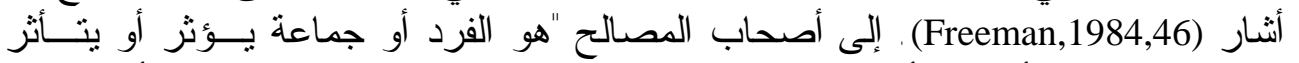

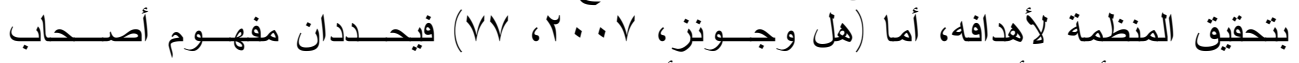

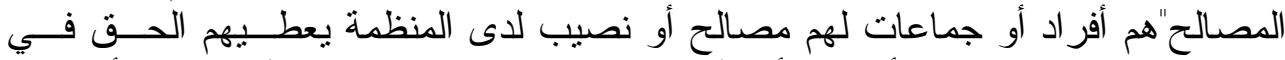

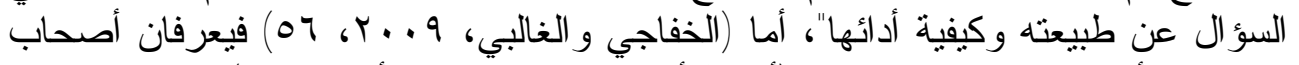

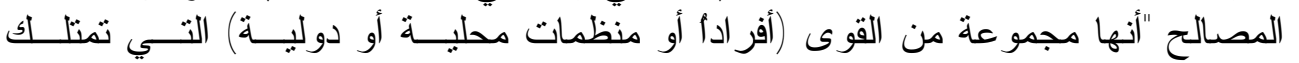

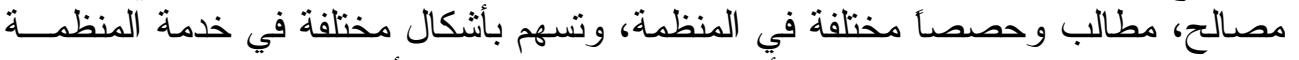

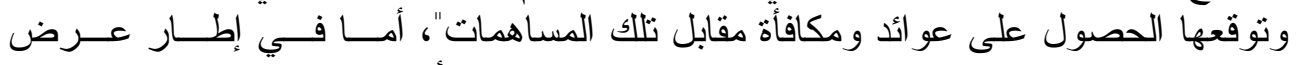

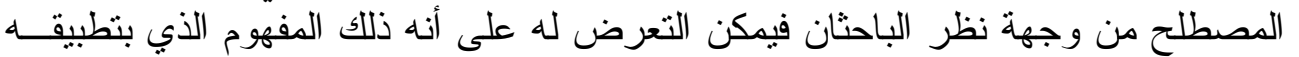

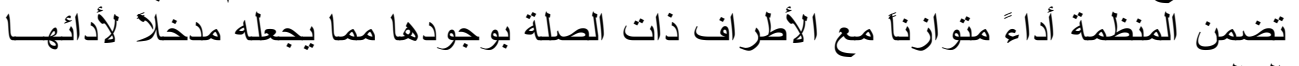
العالي. 


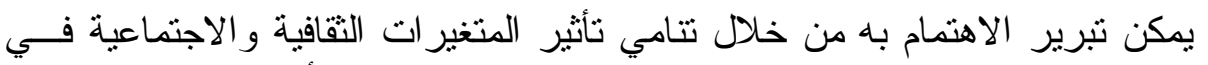

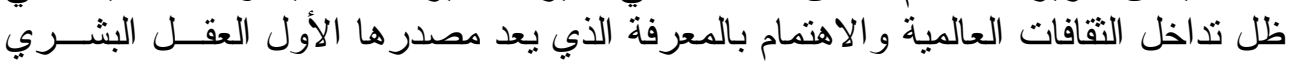

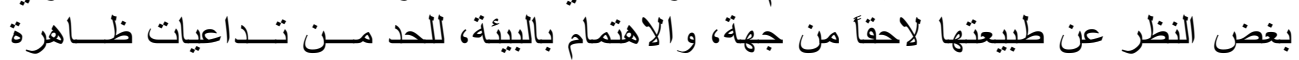

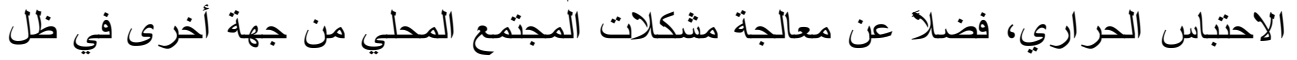

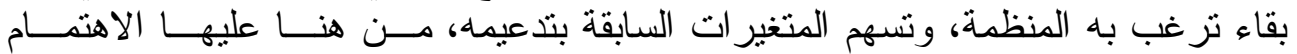

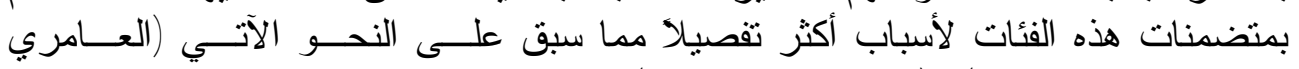

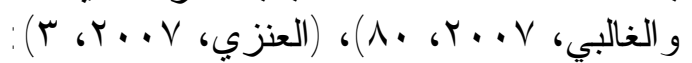

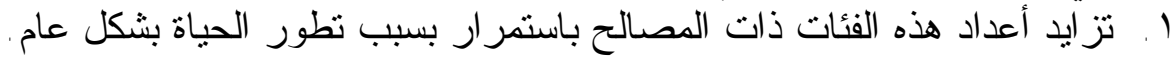

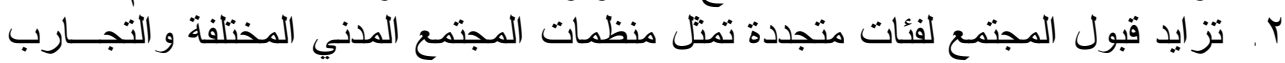

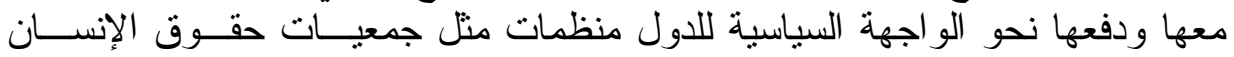
وجمعيات أخرى، وأصبحت ذات تأثثر مهم وكبير ، ولعل الأكثر وضوحاً هو ما بدأت التهات

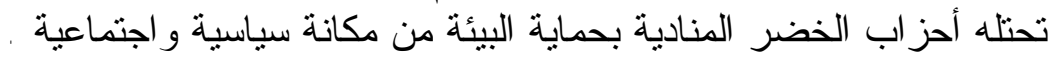

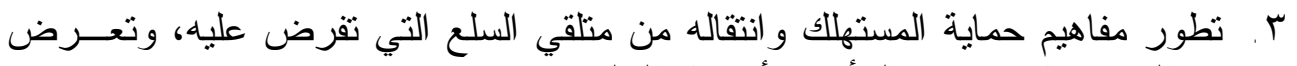

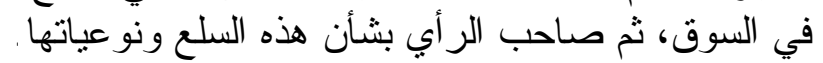

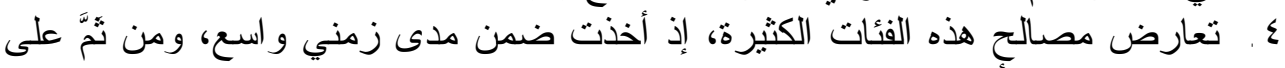

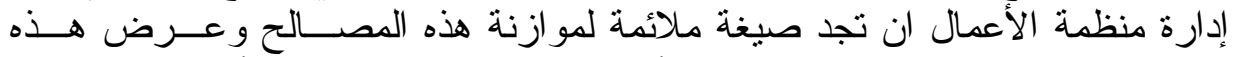

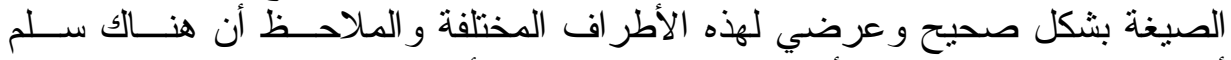

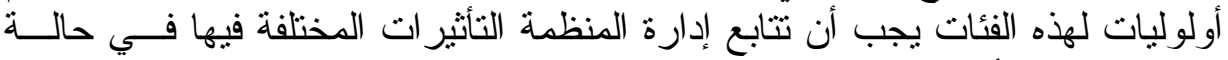

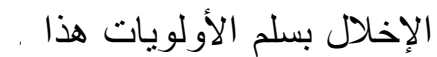

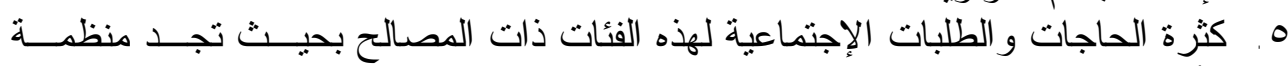

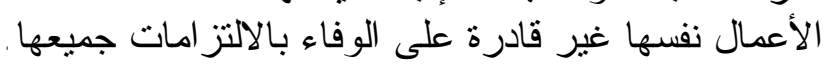

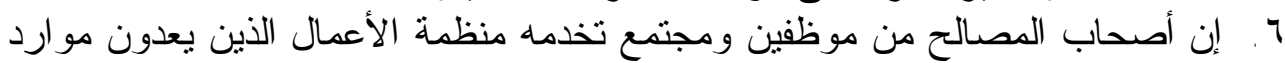

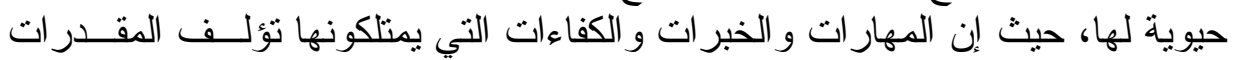
التظيمية لها.

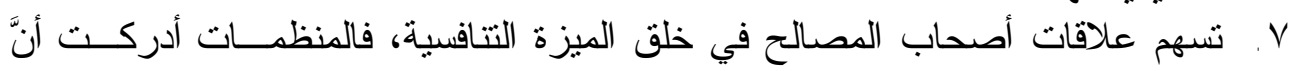

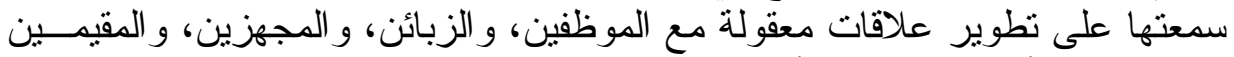

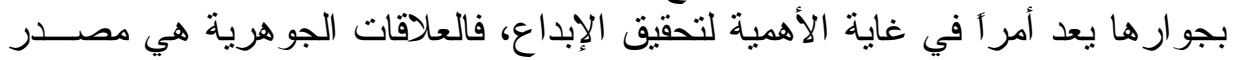

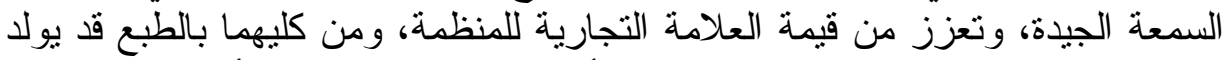

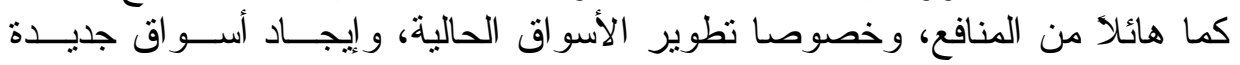

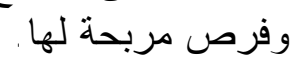

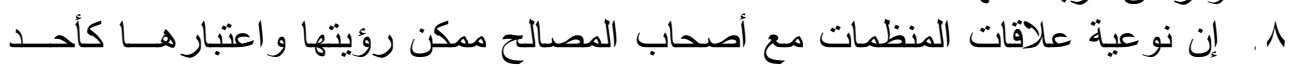

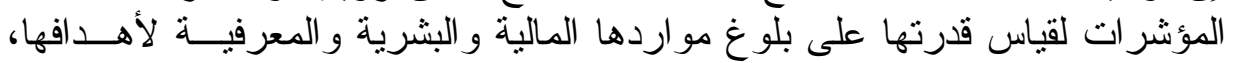

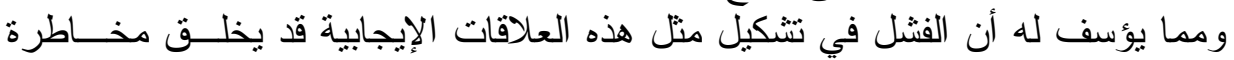

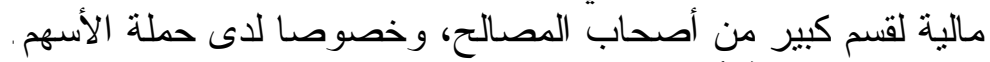

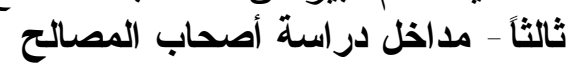

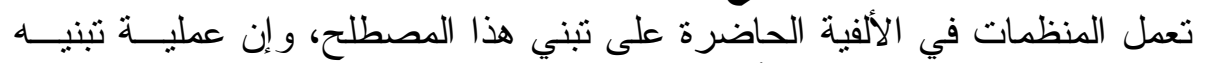

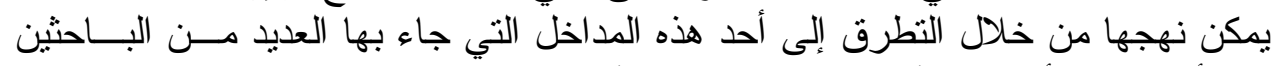

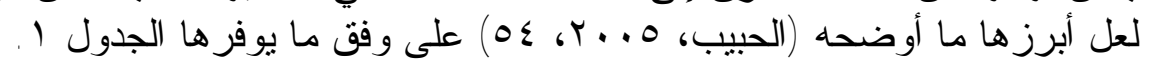




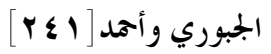

\begin{tabular}{|c|c|}
\hline \multicolumn{2}{|l|}{ 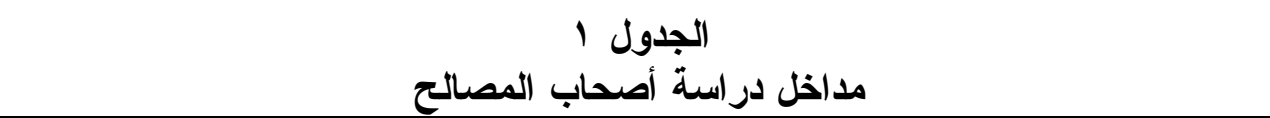 } \\
\hline المفهوم للمدخل & المدخل \\
\hline 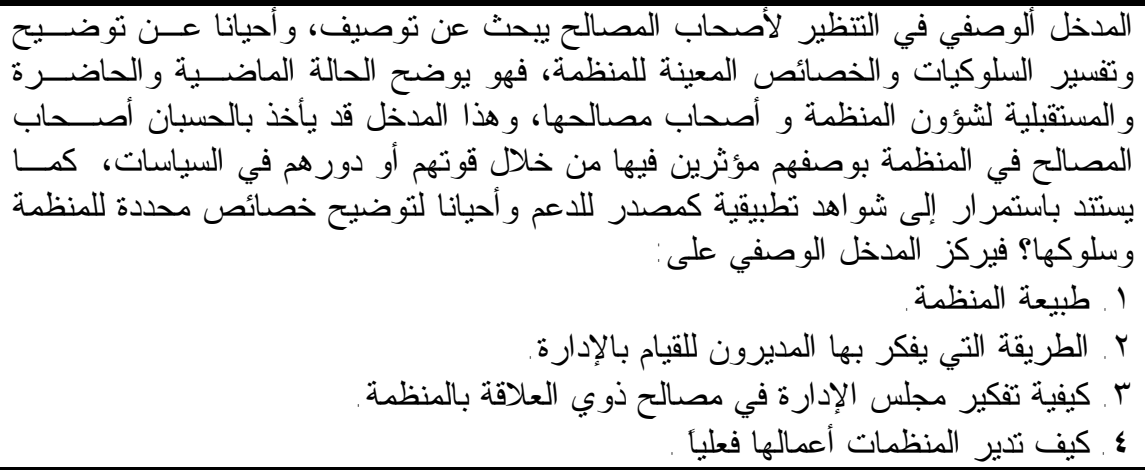 & \\
\hline 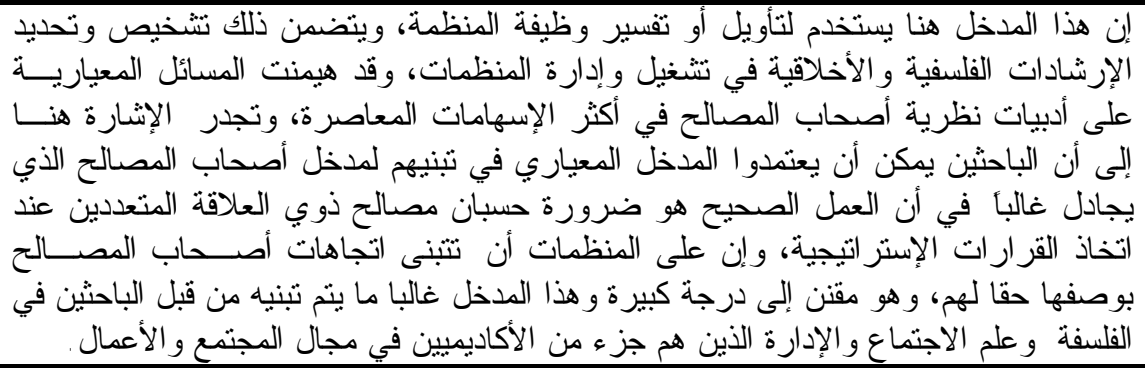 & \\
\hline 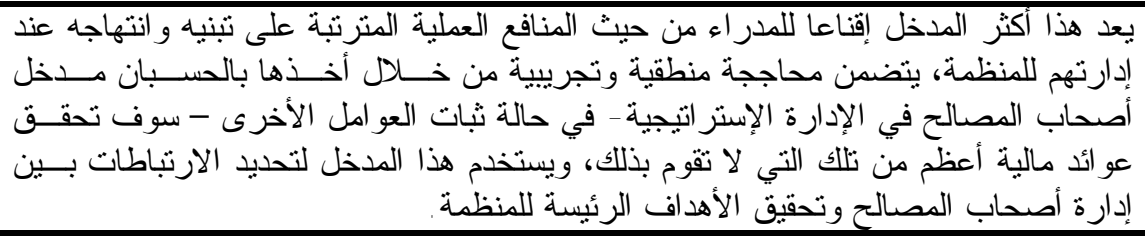 & \\
\hline 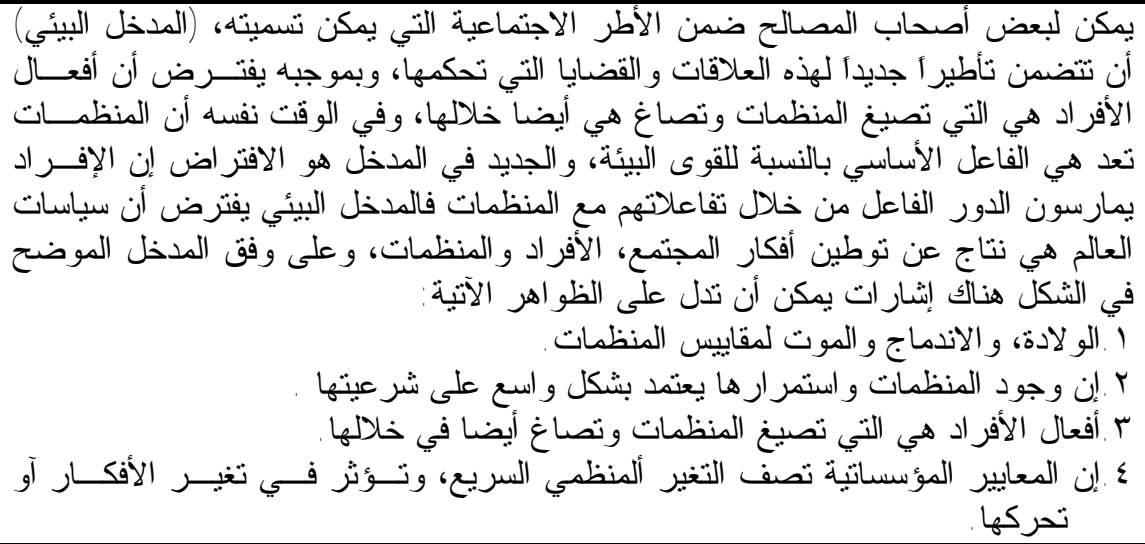 & 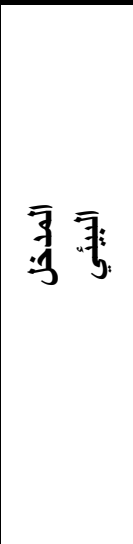 \\
\hline 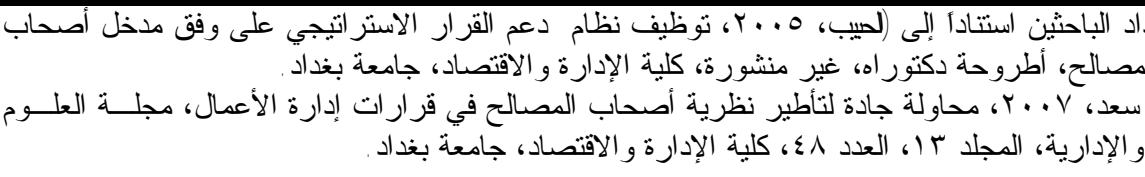 & \\
\hline
\end{tabular}




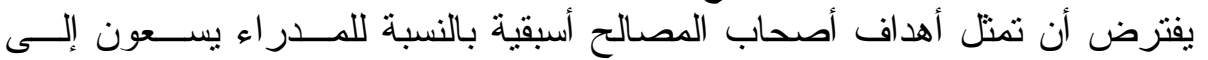

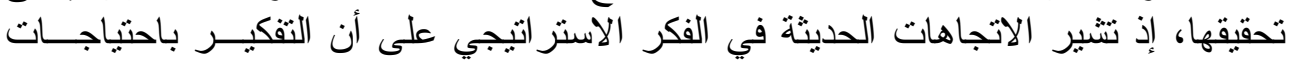

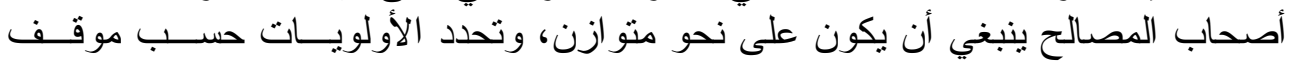

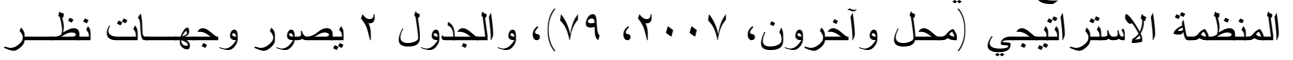

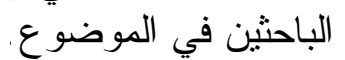

\begin{tabular}{|c|c|c|c|c|c|c|c|c|}
\hline \multicolumn{9}{|c|}{ علجى وفث آراء } \\
\hline 事事 & 牙 & 可 & 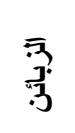 & 3. & 多事 & 事 & فئات أصحاب المصالح & 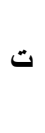 \\
\hline$\sqrt{ }$ & $\sqrt{ }$ & $\sqrt{ }$ & $\sqrt{ }$ & $\sqrt{ }$ & $\sqrt{ }$ & $\sqrt{ }$ & 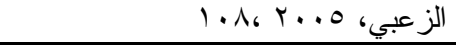 & .1 \\
\hline$\sqrt{ }$ & $\sqrt{ }$ & $\sqrt{ }$ & $\sqrt{ }$ & & & $\sqrt{ }$ & 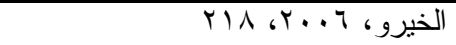 &. $\mathrm{r}$ \\
\hline$\sqrt{ }$ & $\sqrt{ }$ & $\sqrt{ }$ & $\sqrt{ }$ & $\sqrt{ }$ & $\sqrt{ }$ & $\sqrt{ }$ & 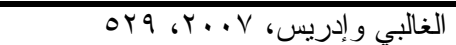 & $r$ \\
\hline$\sqrt{ }$ & $\sqrt{ }$ & $\sqrt{ }$ & $\sqrt{ }$ & $\sqrt{ }$ & & $\sqrt{ }$ & 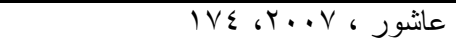 & . \\
\hline & $\sqrt{ }$ & $\sqrt{ }$ & $\sqrt{ }$ & $\sqrt{ }$ & $\sqrt{ }$ & $\sqrt{ }$ & 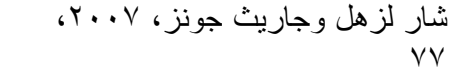 & .0 \\
\hline$\sqrt{ }$ & & $\sqrt{ }$ & $\sqrt{ }$ & & $\sqrt{ }$ & $\sqrt{ }$ & العنزي، V...Y، 0 & .7 \\
\hline$\sqrt{ }$ & & $\sqrt{ }$ & $\sqrt{ }$ & & $\sqrt{ }$ & & 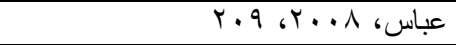 &. $\mathrm{V}$ \\
\hline$\sqrt{ }$ & $\mathrm{V}$ & $\sqrt{ }$ & $\sqrt{ }$ & $\sqrt{ }$ & $\sqrt{ }$ & $\sqrt{ }$ & الغالبي و العامري، 1...T، 90 & 1 \\
\hline & $\sqrt{ }$ & $\sqrt{ }$ & $\sqrt{ }$ & $\sqrt{ }$ & $\sqrt{ }$ & & جاد الرب، · (·ץ، 7 & .9 \\
\hline$V V . V$ & $V V . V V$ & $1 \ldots$ & $1 \ldots$ & 74.7 & VV.V & VV.V & ن ل نسب الاتفاق & \\
\hline
\end{tabular}

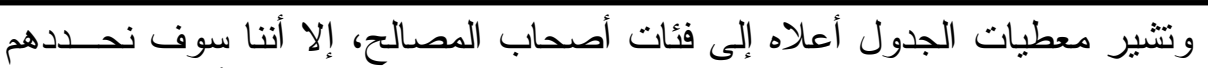
على وفق ما ينسجم مع الميدان المبحوث على الذي يمكن تحديدهم وتحديد أهدافهم و علـــى النحو الآتي: - النيائ

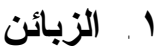

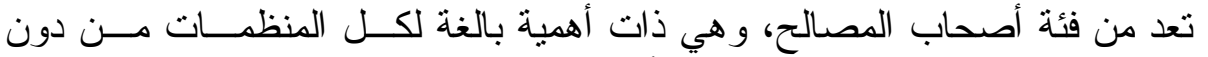

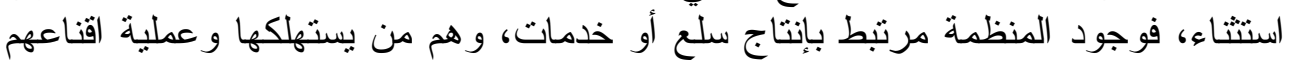

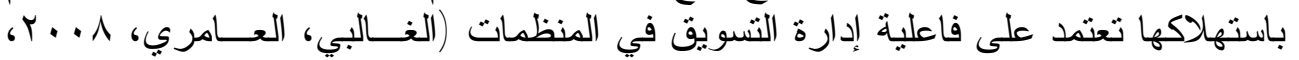

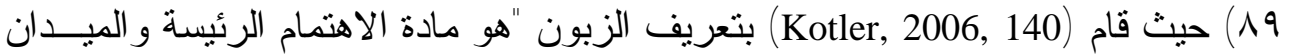

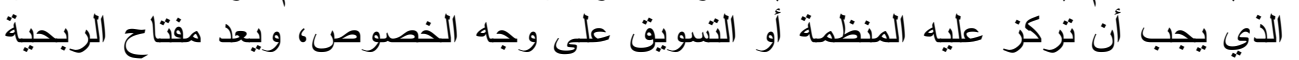

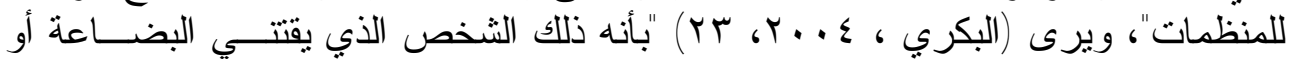

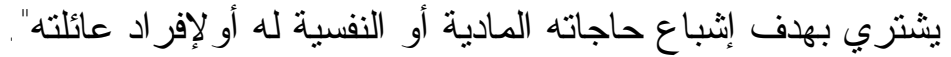

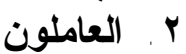
العاملون فئة من فئات أصحاب المصالح، ولقد أصبحت الإدارة على وفق اتجاهاتها

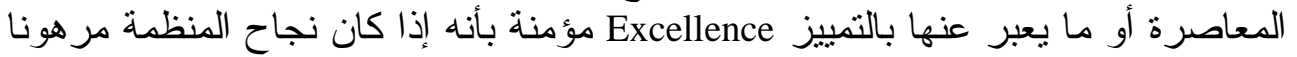

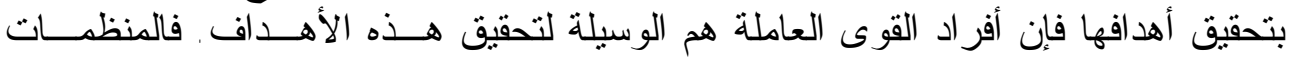

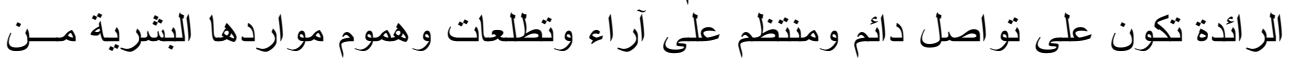




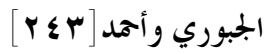

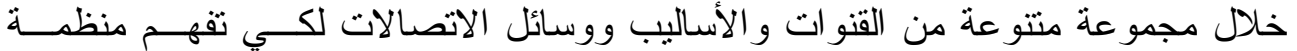

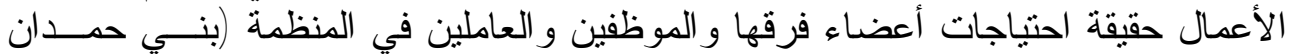

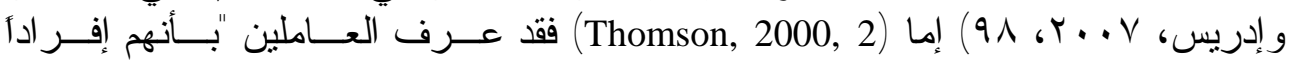

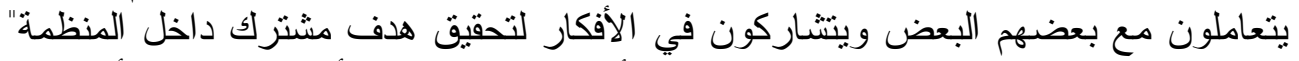

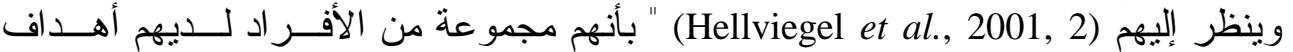

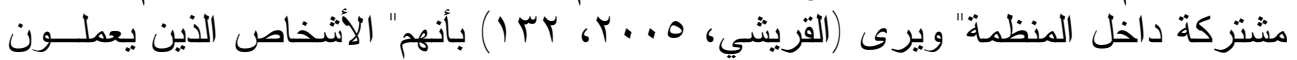

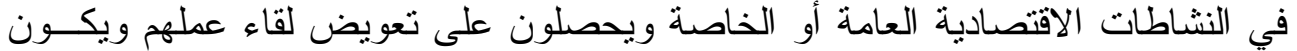

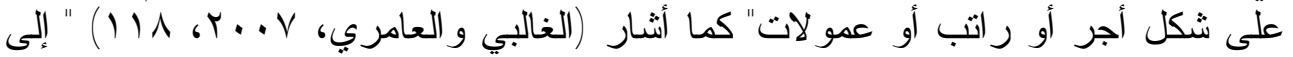

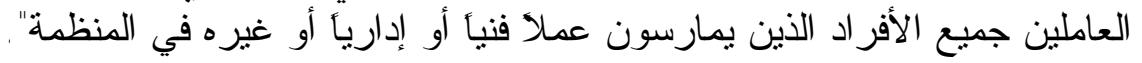

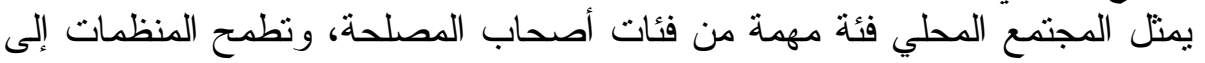

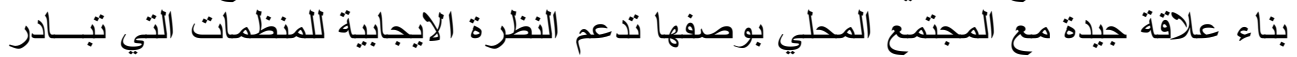

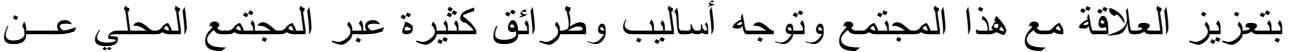

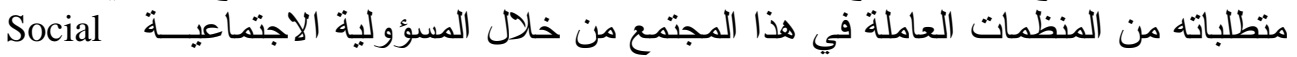
Responsibility

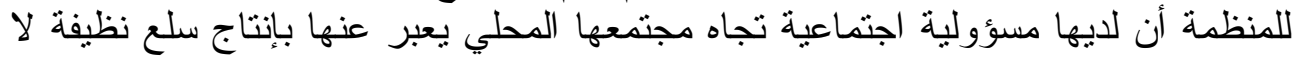

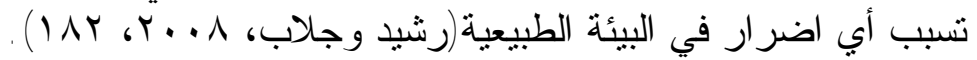

ع. البيئة الطبيعية أفئية

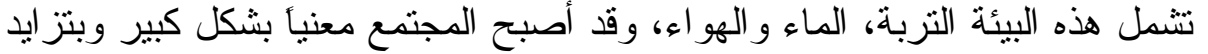

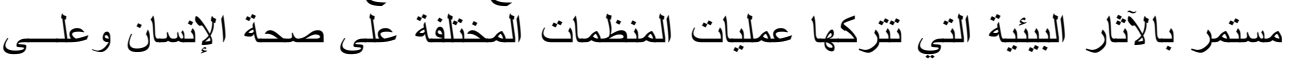

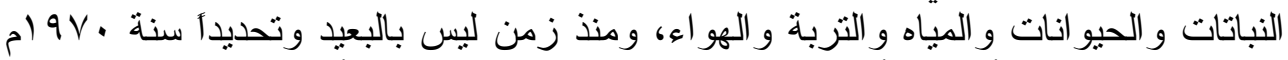

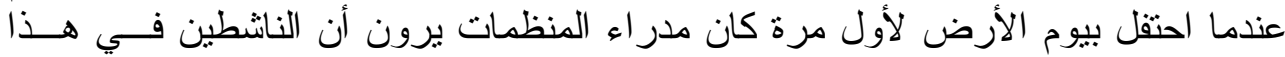

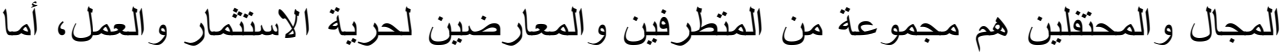

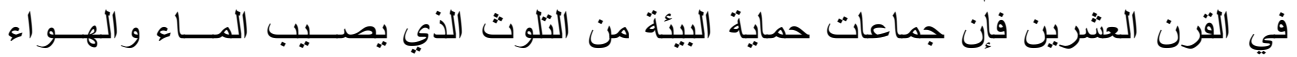

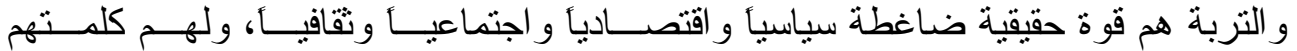

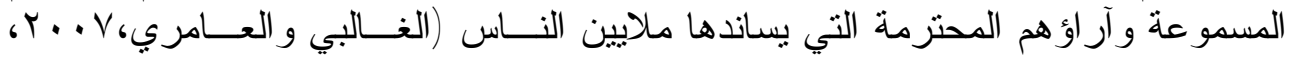

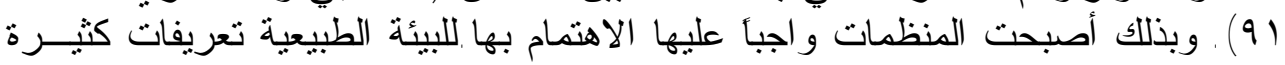

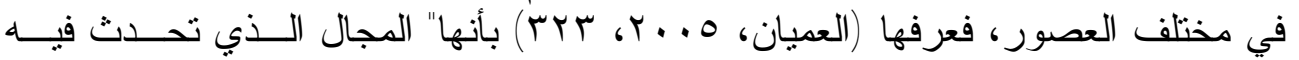

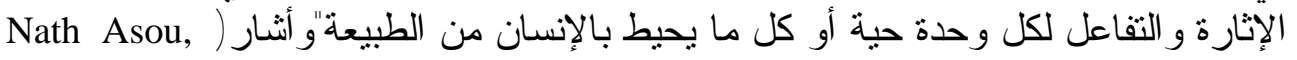

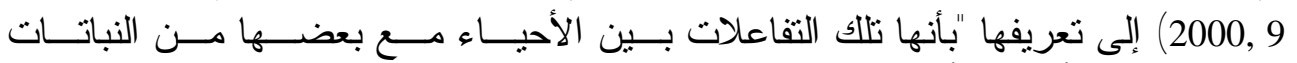

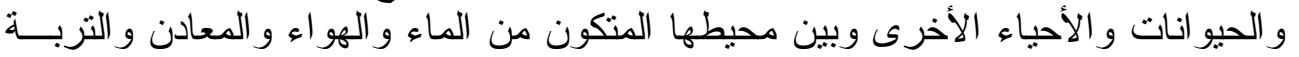

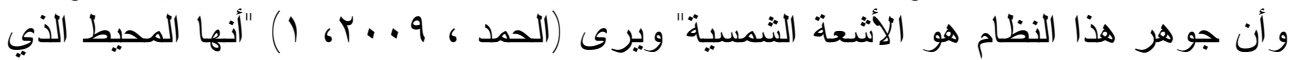

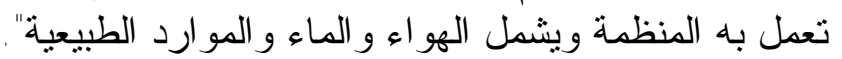
خامساً - مقياس رضا بعض وض من أصحاب المصاء المصأح

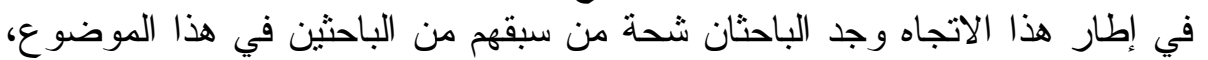

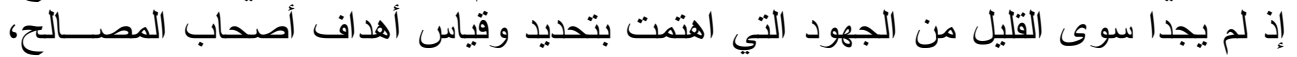

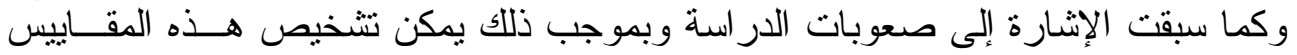

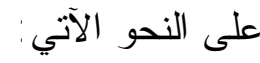




\section{ا امقاييس أهداف الزبائن}

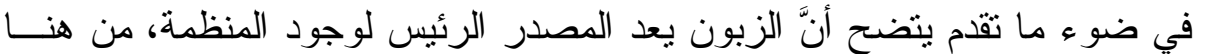

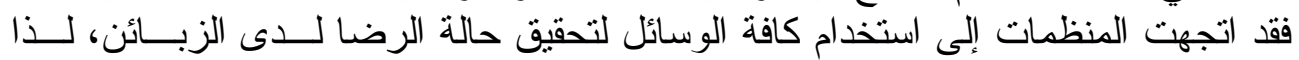

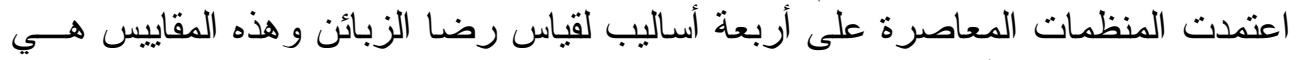

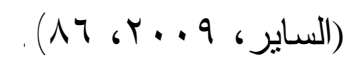
أ. نظم الثكاوى و المقترحات. ب. مسوحات رضا الزبون.

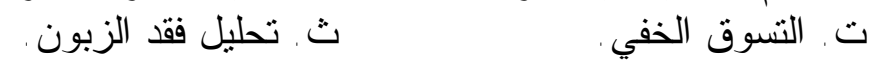

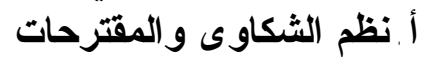

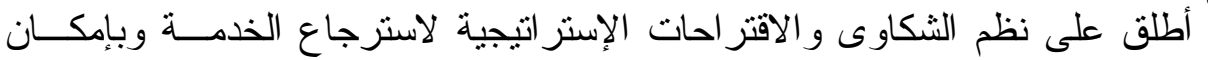

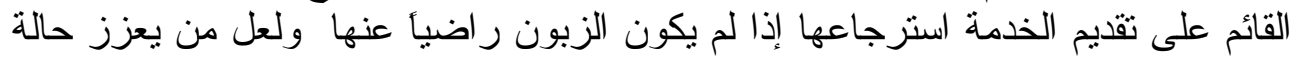

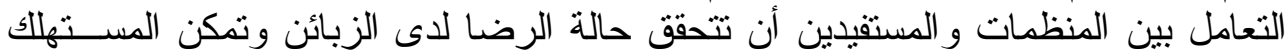

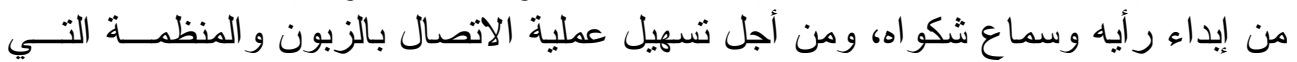

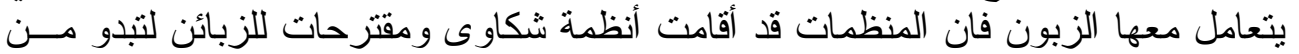

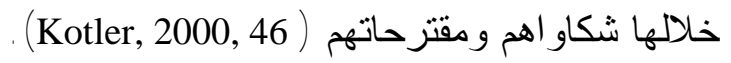
ب. ب مسوحات رضا الزيون.

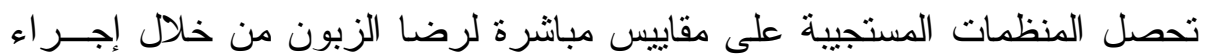

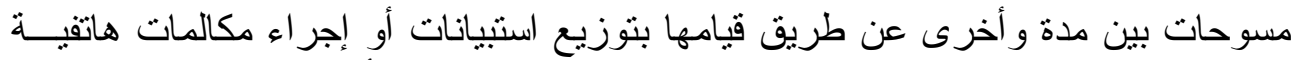

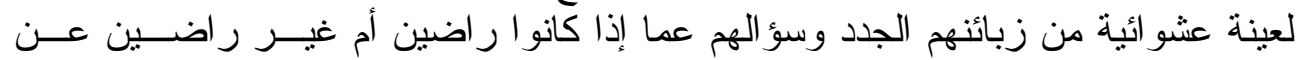

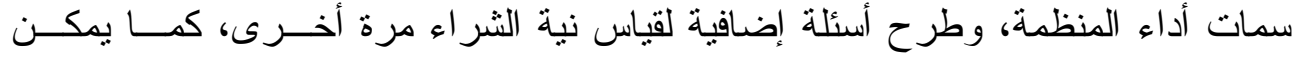

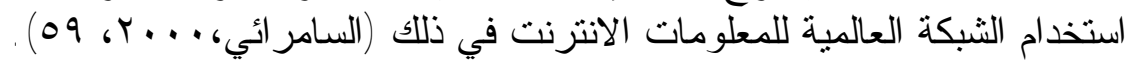

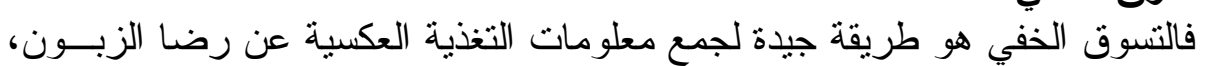
ت. التسوق الخفي

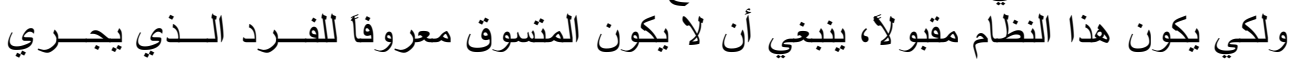

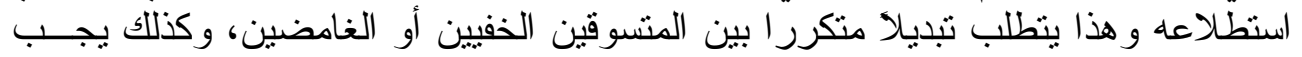

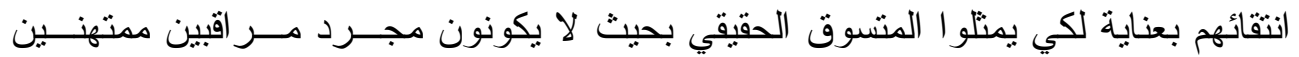

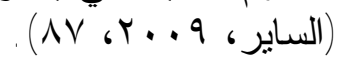

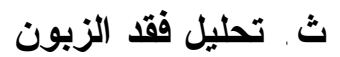

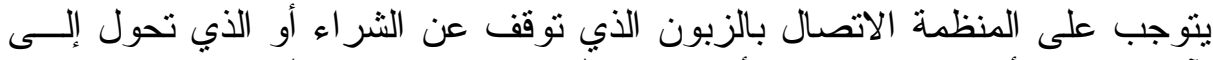

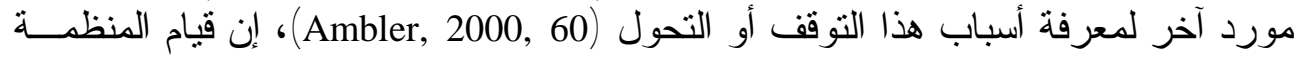

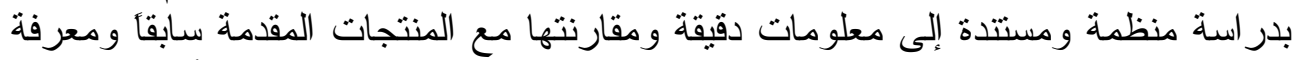

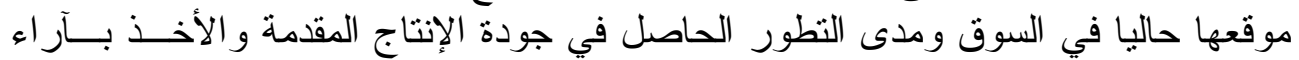

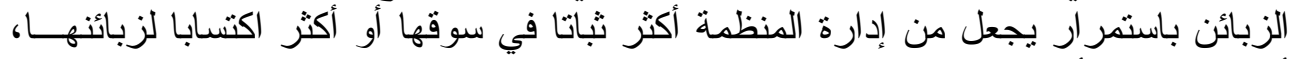

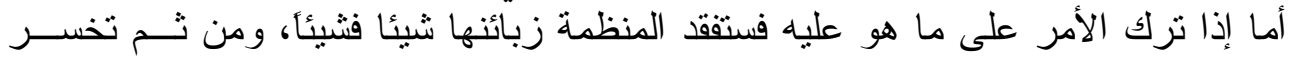

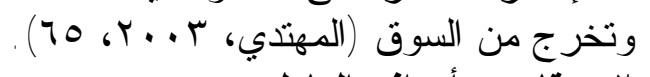

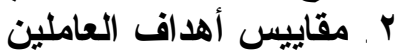

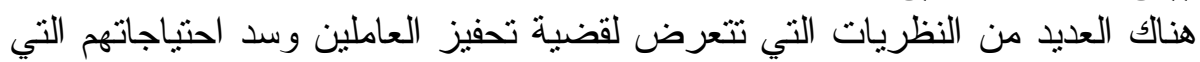

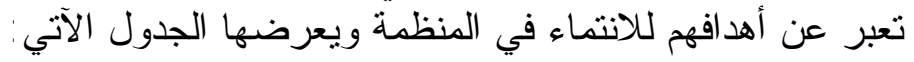


الجبوري وأحد

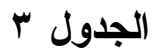

نظريات تحفيز العاملين

\begin{tabular}{|c|c|c|c|}
\hline 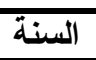 & اسم الباحث & نظريات الدوافع والحو افز على وفق آراء المفكرين & ت \\
\hline 1918 & فرديك تايلور & النظرية النقليدية أَو الكلاسيكية & -1 \\
\hline 194. & التون مايو & نظرية أو حركة العلاقات الإنسانية & $-\overline{-r}$ \\
\hline $190 \leqslant$ & أبر اهام ماسلو & نظرية سلم الحاجات & $-\mu$ \\
\hline 1909 & هرزبوغ & نظرية العاملين & $-\varepsilon$ \\
\hline 197. & دوجلاس مالك غريفور & "y نظرية "x" ونظرية "y & -0 \\
\hline $197 \varepsilon$ & فكتور فروم & نظرية التوقع & -7 \\
\hline 1970 & آدمز & نظرية العدالة & $-v$ \\
\hline 1979 & 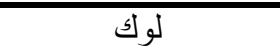 & نظرية وضع الأهداف & $-\Lambda$ \\
\hline $19 V \cdot$ & ديفيد فاك ليلاند & نظرية الانجاز و الانتماء و السلطة & -9 \\
\hline I9VY & الدرفر & نظرية حاجات البقاء و العلاقات النمو & 1. \\
\hline
\end{tabular}

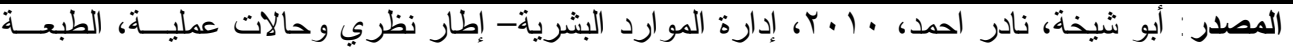

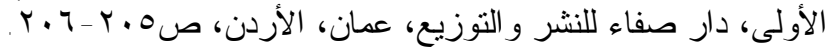

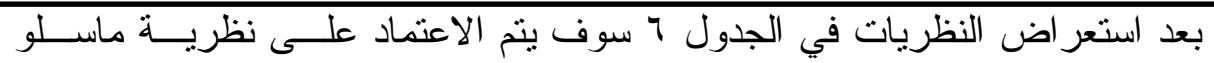

$$
\text { لانسجامها مع توجهات الدر استة الفرات }
$$

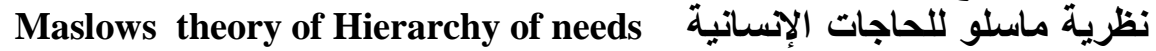

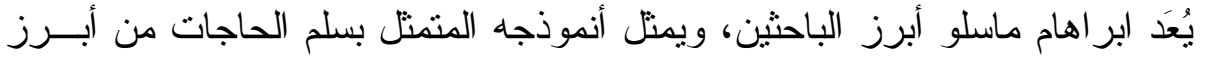

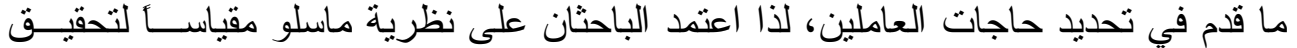

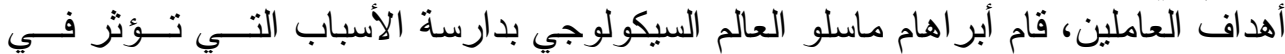

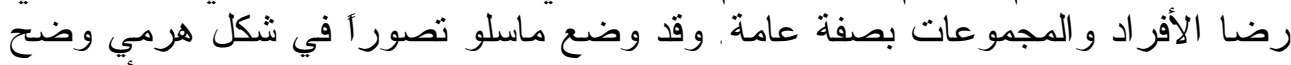

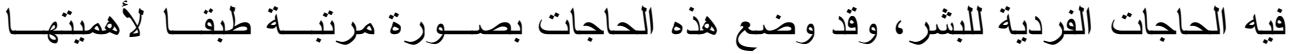

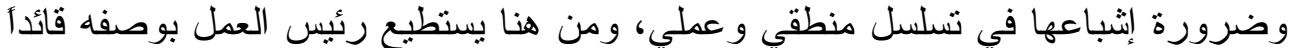

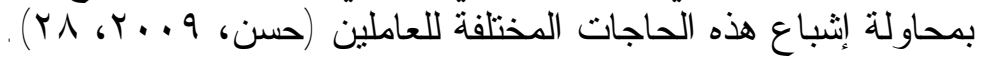

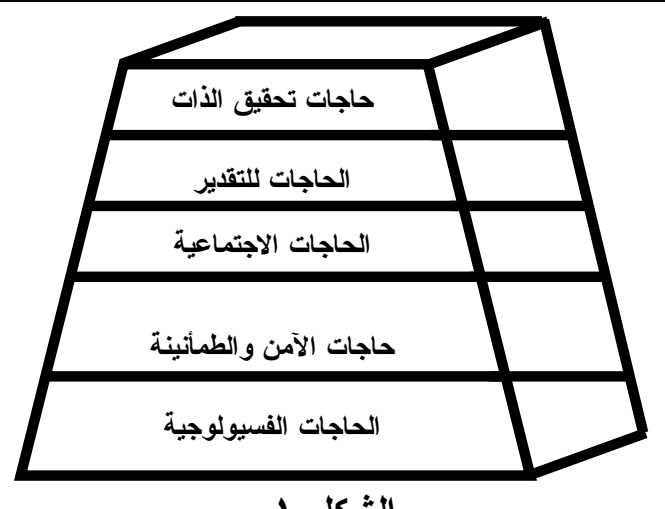

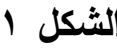

هرم الحاجات لماسلو

Source: Setphen P. Robins, personnel: The Management of Human Resource, Englewood cliffs, New Jersey prentice - Hell, Inc., 1978. p.196. 
أ - الحاجات الفسيولوجية Physiological Needs

الحاجات الفسيولوجية مثل الحاجة إلى الطعام و الماء و الأوكسجين و النوم، هي أكثر

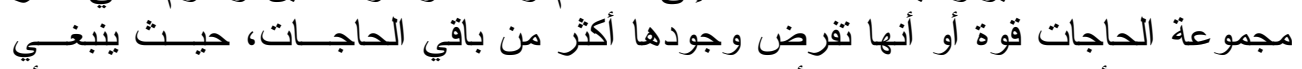

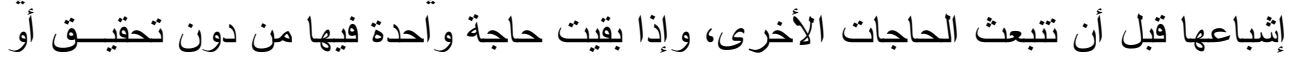

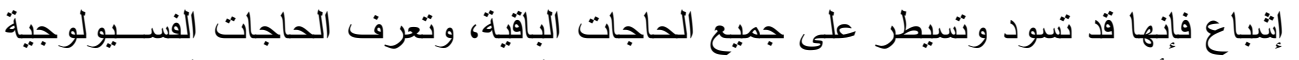

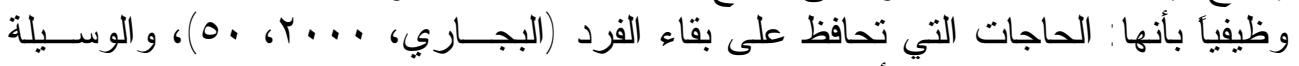

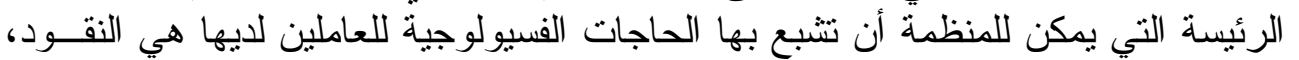

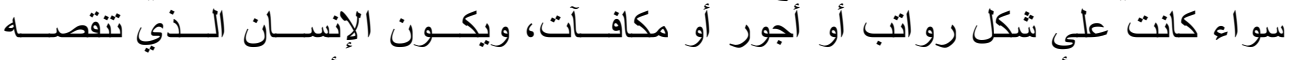

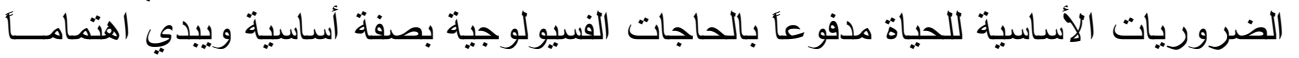

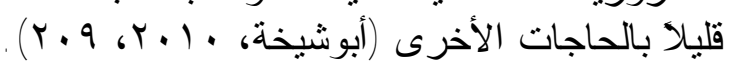

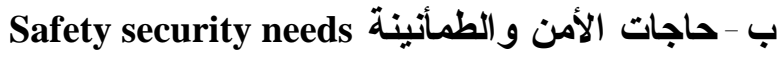

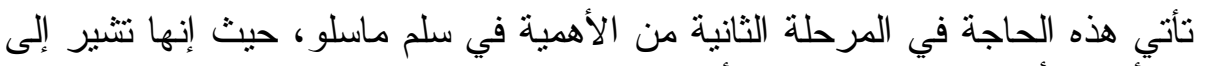

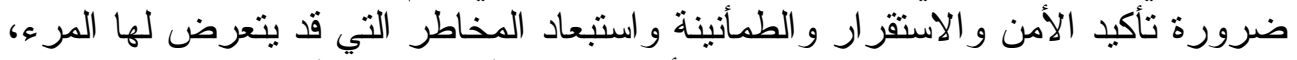

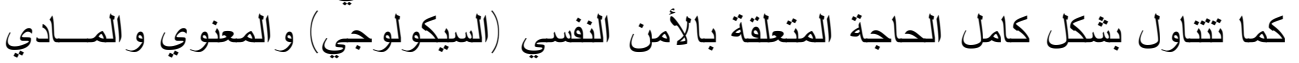

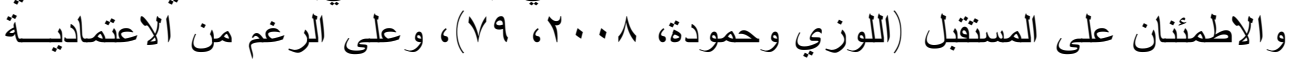

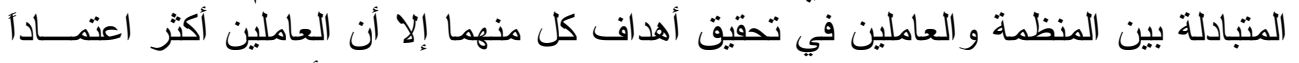

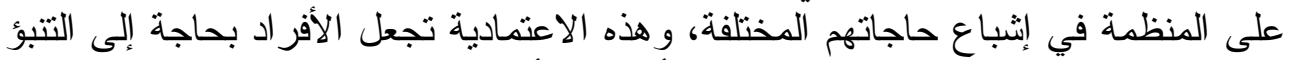

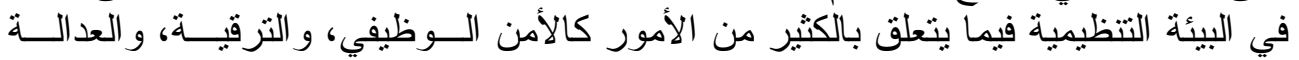

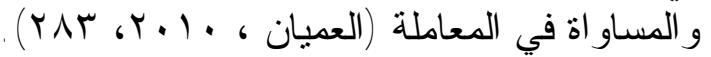

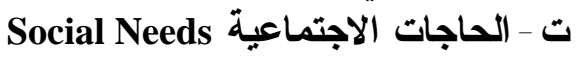

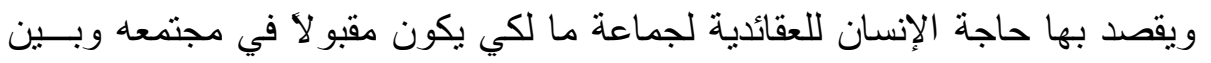

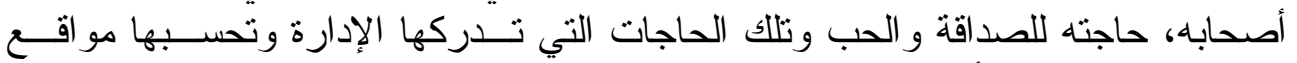

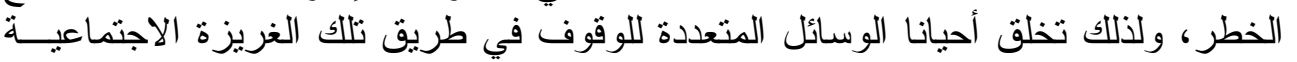

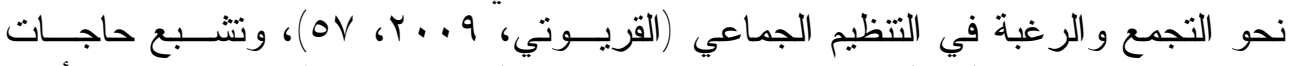

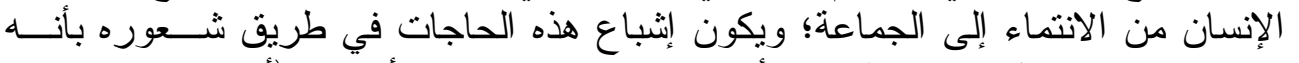

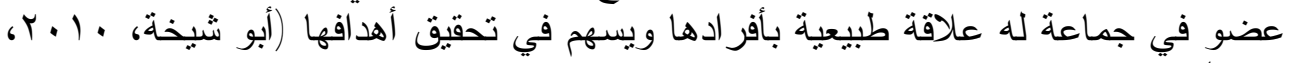

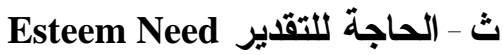

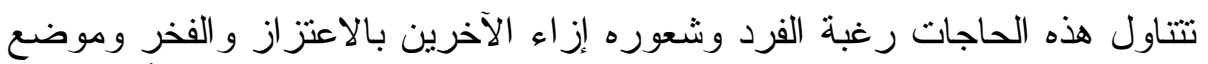

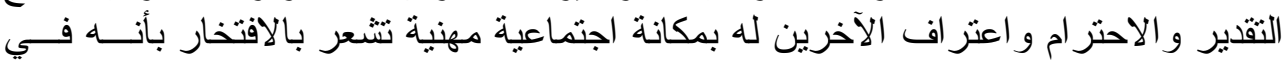

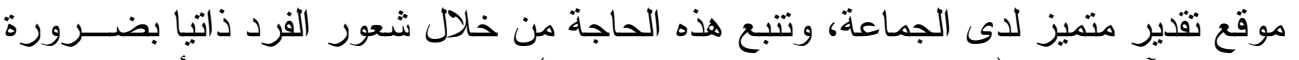

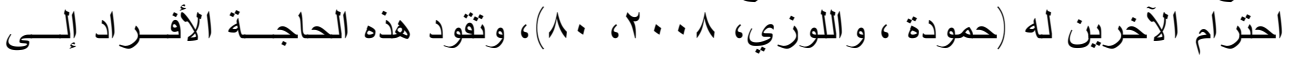

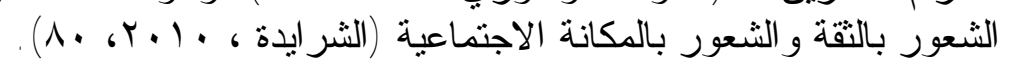

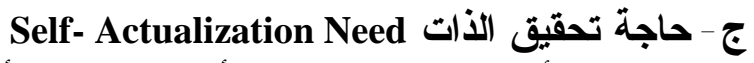

عند تأمين جميع الحاجات الأخرى يسعى الأفر اد نحو تحقيق ذاتهم، ويجاهدون مستـن

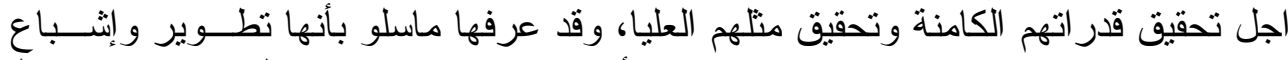

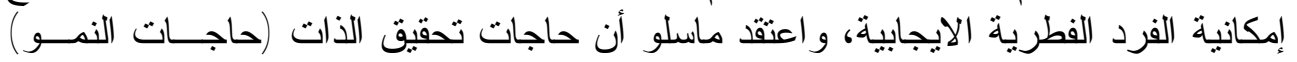

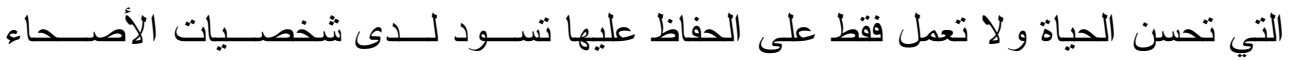


الجبوري وأهد

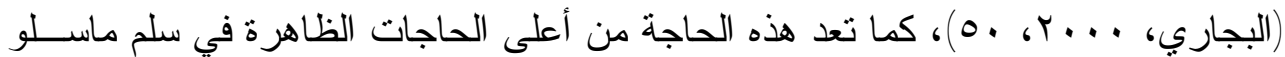

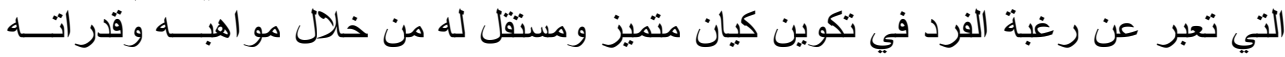

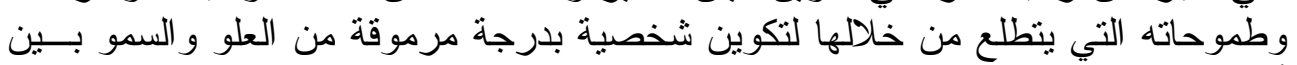

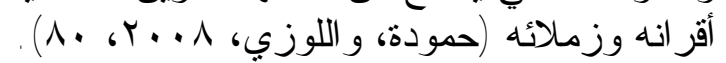

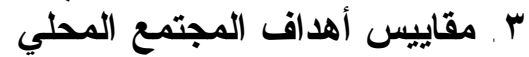

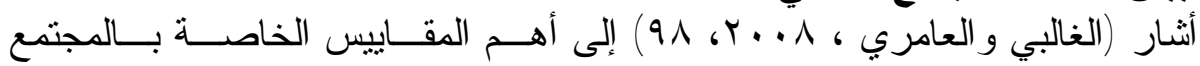

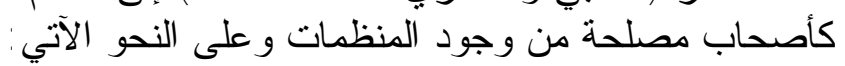

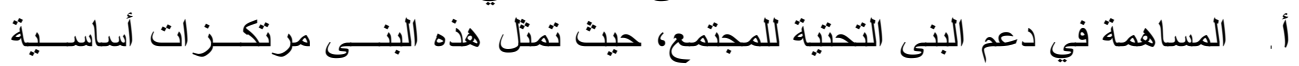

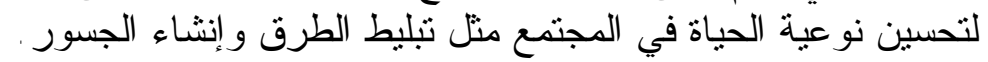

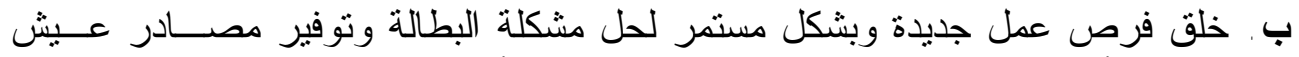

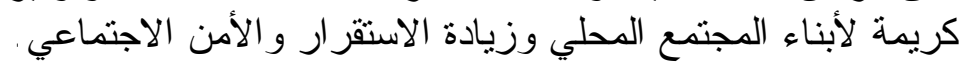

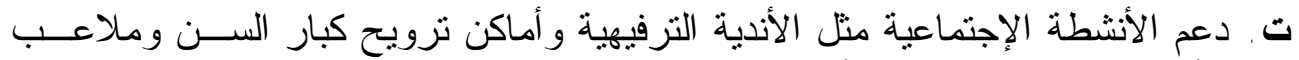

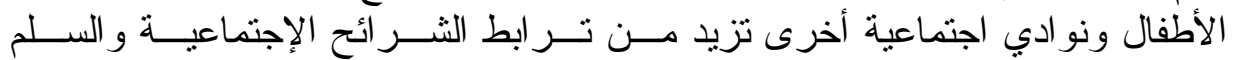
الاجتماعي وتقليل الإضطر ابات فيه الإنه

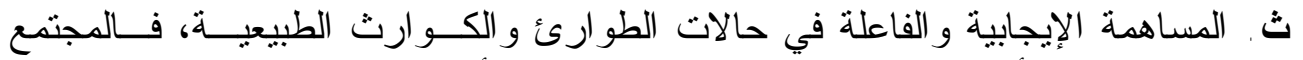

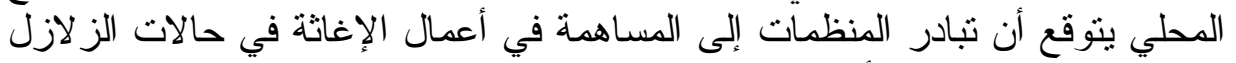
و الفيضانات و الحروب الأهلية و الحريق و الإضطر أبات السيات السياسية.

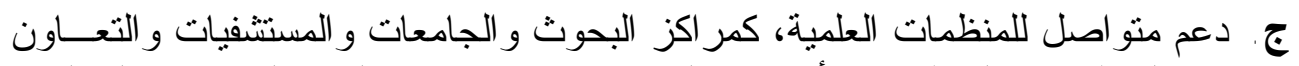

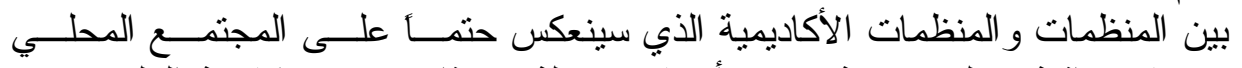

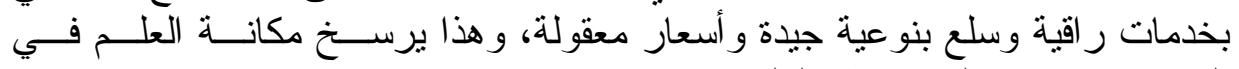

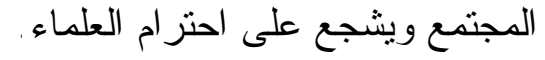

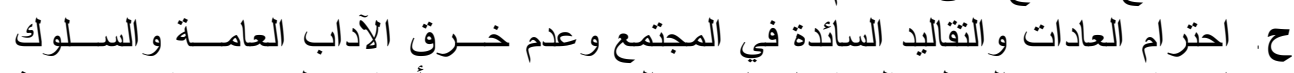

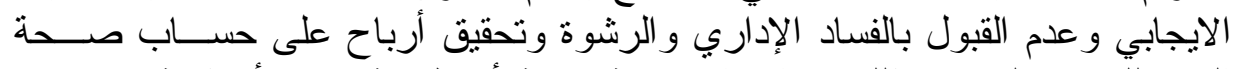
الكستهلك مستغلين في ذلك عادات اجتماعية معينة أو طريقة تفكير أو نقافة سائدة في

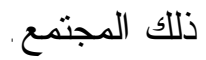
خ. دعم منظمات المجتمع المدني، و هذه تتمتل بمجمو عة كبيرة من الجمعيات و المنظمات

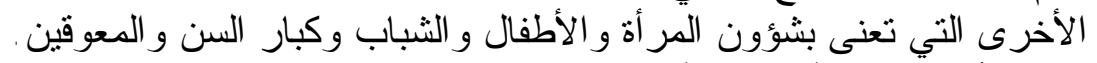

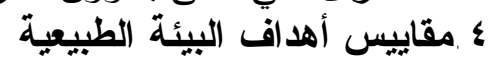

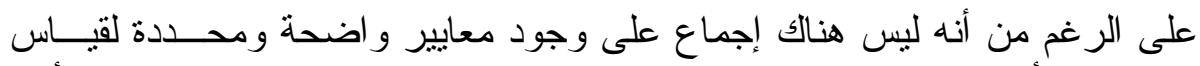

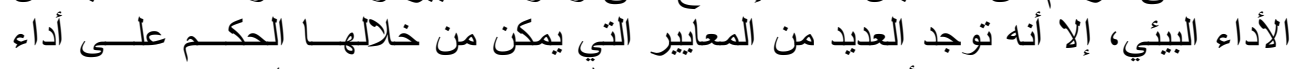

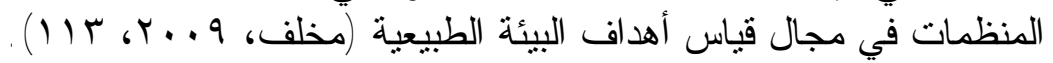

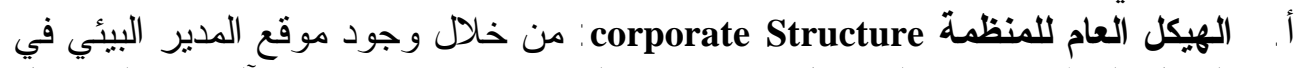

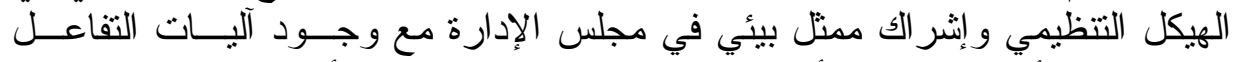

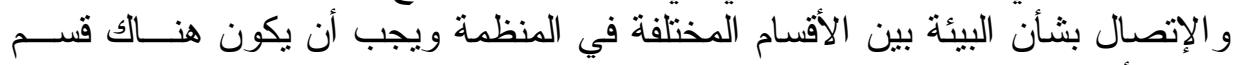

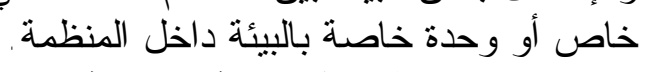

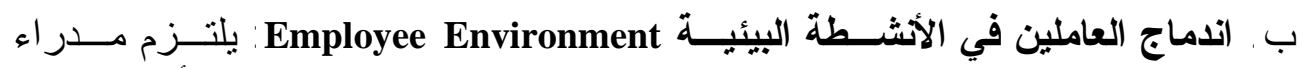
المنظمات بتربية وتنريب العاملين فيما يخص شؤون البيئة وتحفيز ومكافأة العساملين 
المتميزين في مجال الأنشطة البيئية، كما يجب أن تتوفر ظروف عمل جيدة للعساملين

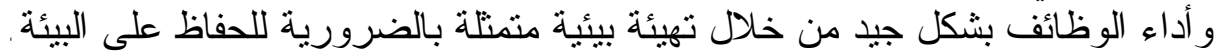

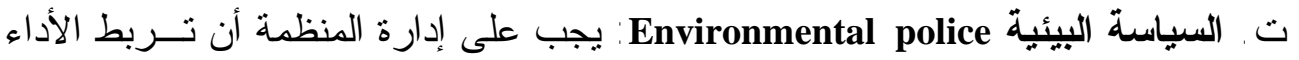

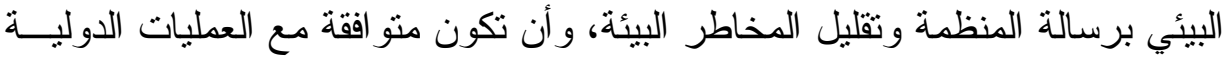
للمنظمة بشرط الإستدامة بالنشاط البيئي.

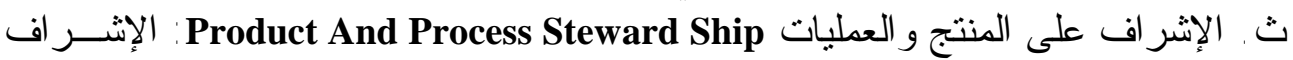

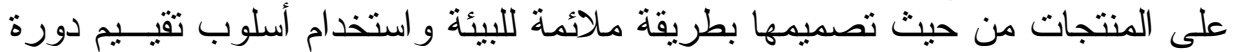

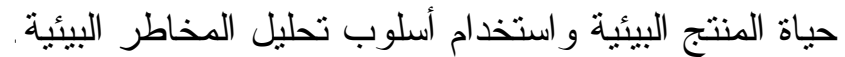

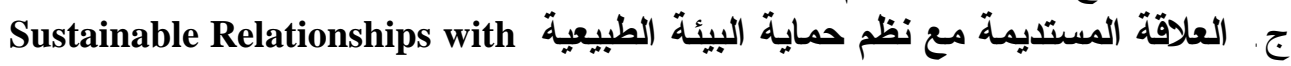
Natural Ecosystems

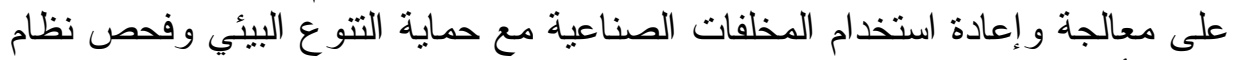

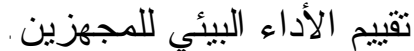

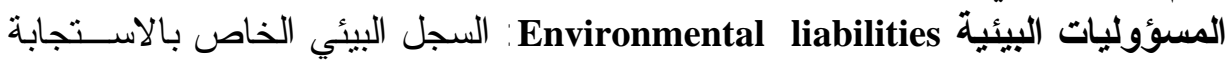

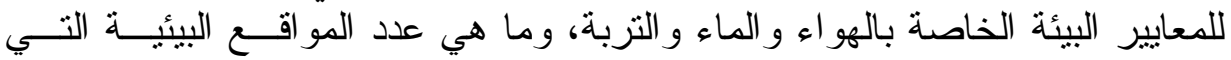

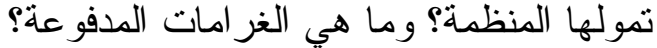

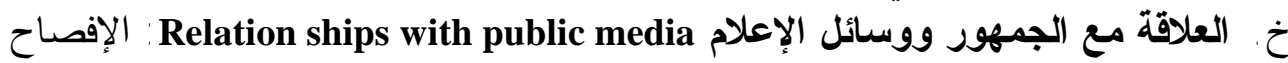

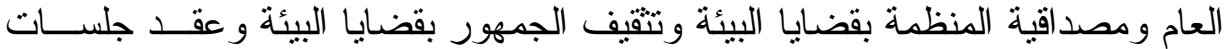
حوار مع المجتمع المحلي حول قضايا البيئة و العدالة باختيار مواقع الوحدات الإنتاجية

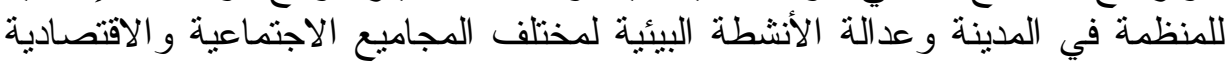

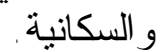
د. . اتصالات تغطي الأنشطة البيئية Communication of environmental activity: من

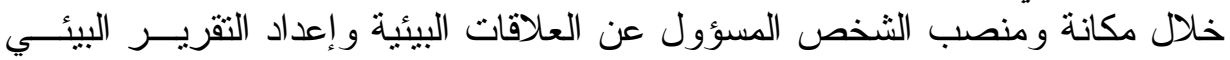

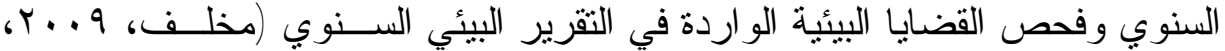

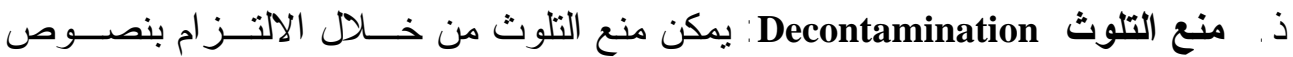

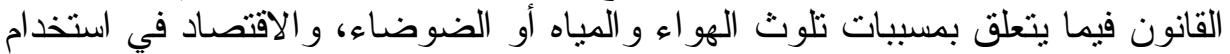

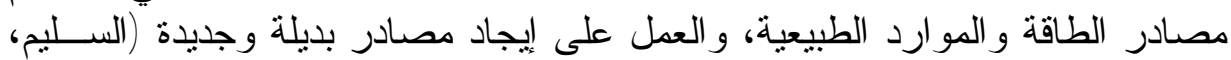
. () I V r...

الجانب التطبيقي

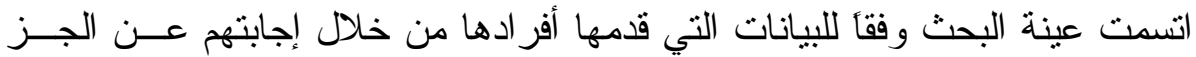

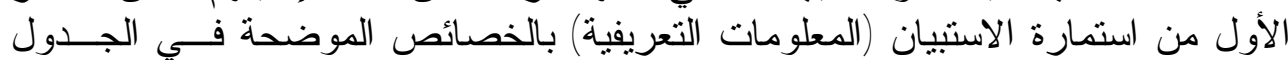


الجبوري وأهد

\begin{tabular}{|c|c|c|}
\hline \multicolumn{3}{|c|}{ وصف الأفراد المبحولثين } \\
\hline \multicolumn{3}{|c|}{ الجنس } \\
\hline النسبة المئوية & العدد & الجنس \\
\hline$\Lambda \cdot, 9 \wedge 0$ & $\wedge \wedge$ & ذكر \\
\hline 19.910 & $r$ & أنثى \\
\hline$\% 1 \ldots$ & 1.9 & المجموع \\
\hline \multicolumn{3}{|c|}{ الفئات العمرية } \\
\hline النسبة المئوية & العدد & الفئات العمرية \\
\hline $17 . \leqslant \leqslant 0$ & 11 & $r q-r_{0}$ \\
\hline$r \varepsilon . T V V$ & $r \Lambda$ & $r \varepsilon-r$. \\
\hline $17 . \wedge Y$. & 11 & $r q-r_{0}$ \\
\hline 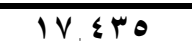 & 19 & $\varepsilon \varepsilon-\varepsilon$ \\
\hline 15.901 & 17 & 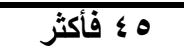 \\
\hline$\% 1 \ldots$ & 1.9 & المجموع \\
\hline \multicolumn{3}{|c|}{ التحصيل العلمي } \\
\hline$\varepsilon . \leqslant 70$ & 0 & إعدادية \\
\hline $7.18 V$ & $\bar{v}$ & دبلوم \\
\hline 10.110 & 94 & بكالوريوس \\
\hline Y.TVV & $r$ & دبلوم عالي \\
\hline$\cdot . \wedge 9 \mathrm{Y}$ & 1 & ماجستير \\
\hline$\cdot$ & $\cdot$ & دكتوراه \\
\hline$\% 1 \ldots$ & 1.9 & المجموع \\
\hline \multicolumn{3}{|c|}{ عدد سنوات الخدمة } \\
\hline$r q . r \leqslant v$ & $\varepsilon r$ & 0.1 \\
\hline YO.9Y. & $r \wedge$ & $1 .-1$ \\
\hline$r \cdot .10$ & rY & $10-11$ \\
\hline 9.99 & $1 \cdot$ & $r \cdot-17$ \\
\hline $0 . Y r V$ & 7 & $r 0-Y 1$ \\
\hline$\cdot$ & $\cdot$ & (أَكثر \\
\hline$\% 1 \ldots$ & 1.9 & المجموع \\
\hline
\end{tabular}

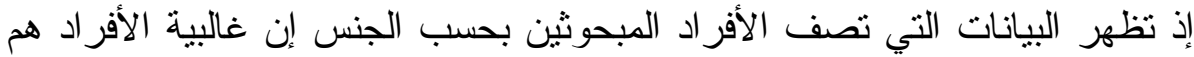

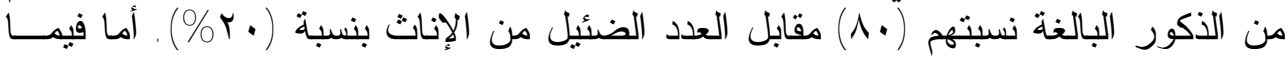

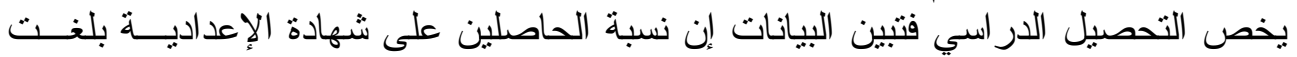

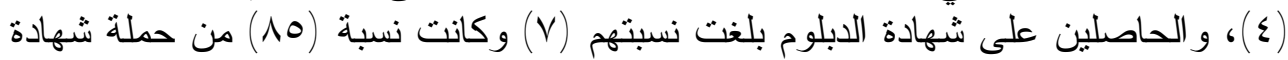

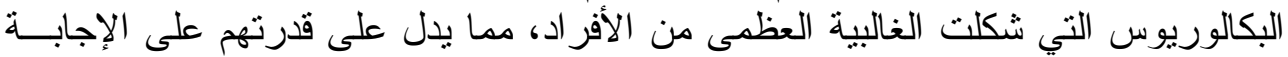

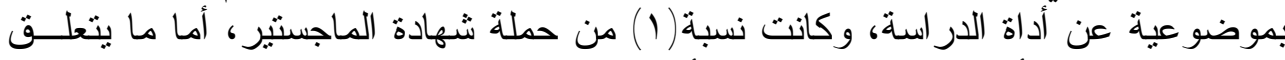

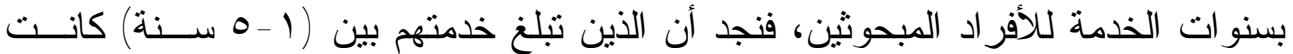




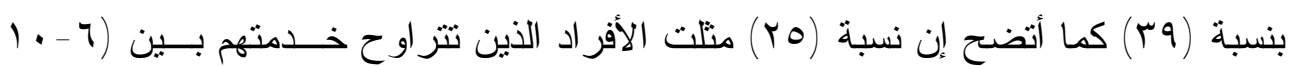

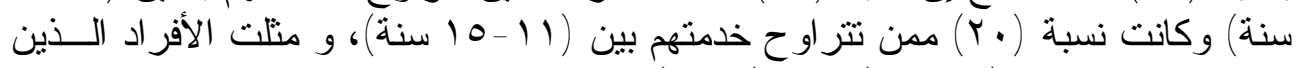

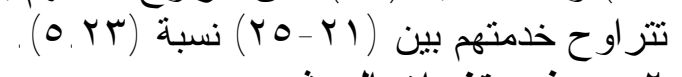

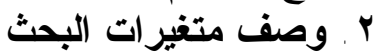

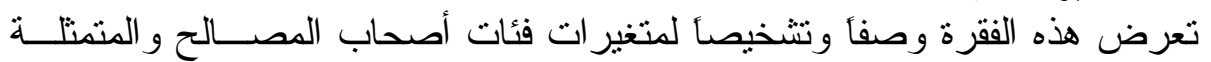

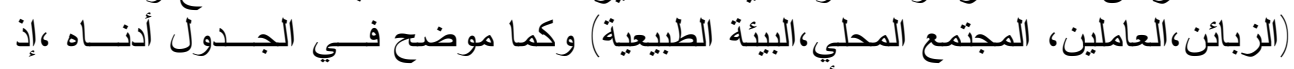

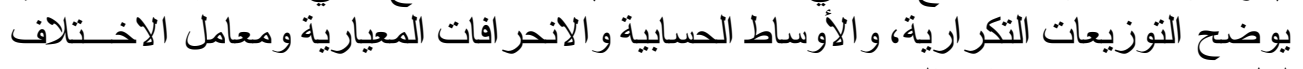

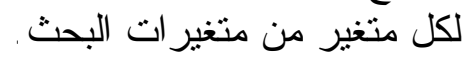

\begin{tabular}{|c|c|c|c|c|c|c|c|c|c|c|}
\hline \multirow{2}{*}{$\begin{array}{l}\text { الاختلاف } \\
\text { C.V } \\
\text { C.V }\end{array}$} & \multirow{2}{*}{ الالحعراف } & \multirow{2}{*}{ الحسابي } & \multicolumn{2}{|c|}{ لا أتفق 1} & \multicolumn{2}{|c|}{ محايد r } & \multicolumn{2}{|c|}{ أتفق r } & \multirow{2}{*}{ الأبعاد } & \multirow{2}{*}{ العو امل } \\
\hline & & & $\%$ & التكر ار & $\%$ & التكر ار & $\%$ & التكر ار & & \\
\hline 0.308 & 0.58 & 1.88 & 46.15 & 12 & 19.23 & 5 & 34.62 & 9 & $\mathrm{x} 1$ & \multirow{7}{*}{$\begin{array}{l}\text { c. } \\
\text { E. } \\
\text { E. } \\
\underline{E}\end{array}$} \\
\hline 0.338 & 0.60 & 1.77 & 50.00 & 13 & 23.08 & 6 & 26.92 & 7 & $\mathrm{x} 2$ & \\
\hline 0.580 & 0.76 & 1.31 & 80.77 & 21 & 7.69 & 2 & 11.54 & 3 & $\mathrm{x} 3$ & \\
\hline 0.366 & 0.62 & 1.69 & 46.15 & 12 & 38.46 & 10 & 15.38 & 4 & $\mathrm{x} 4$ & \\
\hline 0.680 & 0.81 & 1.19 & 84.62 & 22 & 11.54 & 3 & 3.85 & 1 & $\mathrm{x} 5$ & \\
\hline 0.273 & 0.58 & 2.12 & 26.92 & 7 & 34.62 & 9 & 38.46 & 10 & $\mathrm{x6}$ & \\
\hline 0.396 & 0.79 & 1.99 & \multicolumn{2}{|c|}{55.77} & \multicolumn{2}{|c|}{22.44} & \multicolumn{2}{|c|}{21.79} & المؤشر الكلي & \\
\hline 0.267 & 0.65 & 2.43 & 17.86 & 5 & 21.43 & 6 & 60.71 & 17 & $\mathrm{x} 1$ & \\
\hline 0.266 & 0.61 & 2.29 & 14.29 & 4 & 42.86 & 12 & 42.86 & 12 & $\mathrm{x} 2$ & \\
\hline 0.267 & 0.64 & 2.39 & 7.14 & 2 & 46.43 & 13 & 46.43 & 13 & $\mathrm{x} 3$ & \\
\hline 0.300 & 0.89 & 2.96 & 0.00 & 0 & 3.57 & 1 & 96.43 & 27 & $\mathrm{x} 4$ & \\
\hline 0.267 & 0.65 & 2.43 & 14.29 & 4 & 28.57 & 8 & 57.14 & 16 & $\mathrm{x} 5$ & \\
\hline 0.284 & 0.77 & 2.71 & 3.57 & 1 & 21.43 & 6 & 75.00 & 21 & $\mathrm{x6}$ & \\
\hline 0.271 & 0.60 & 2.21 & 21.43 & 6 & 35.71 & 10 & 42.86 & 12 & $\mathrm{X} 7$ & \\
\hline 0.275 & 0.96 & 3.49 & \multicolumn{2}{|c|}{11.22} & \multicolumn{2}{|c|}{28.57} & \multicolumn{2}{|c|}{60.20} & المؤشر الكلي & \\
\hline 0.276 & 0.73 & 2.64 & 3.57 & 1 & 28.57 & 8 & 67.86 & 19 & $\mathrm{X} 1$ & \\
\hline 0.271 & 0.69 & 2.54 & 7.14 & 2 & 32.14 & 9 & 60.71 & 17 & $\mathrm{X} 2$ & \\
\hline 0.272 & 0.68 & 2.50 & 10.71 & 3 & 28.57 & 8 & 60.71 & 17 & $\mathrm{X} 3$ & \\
\hline 0.268 & 0.66 & 2.46 & 10.71 & 3 & 32.14 & 9 & 57.14 & 16 & $\mathrm{X} 4$ & \\
\hline 0.267 & 0.64 & 2.39 & 21.43 & 6 & 17.86 & 5 & 60.71 & 17 & $\mathrm{X} 5$ & \\
\hline 0.268 & 0.66 & 2.46 & 10.71 & 3 & 32.14 & 9 & 57.14 & 16 & $\mathrm{X} 6$ & \\
\hline 0.272 & 0.70 & 2.57 & 7.14 & 2 & 28.57 & 8 & 64.29 & 18 & $\mathrm{X7}$ & \\
\hline 0.266 & 0.60 & 2.25 & 10.71 & 3 & 53.57 & 15 & 35.71 & 10 & $\mathrm{X} 8$ & \\
\hline 0.271 & 0.60 & 2.21 & 14.29 & 4 & 50.00 & 14 & 35.71 & 10 & $\mathrm{X} 9$ & \\
\hline 0.272 & 1.20 & 4.41 & \multicolumn{2}{|c|}{10.71} & \multicolumn{2}{|c|}{33.73} & \multicolumn{2}{|c|}{55.56} & المؤشر الكلي & \multirow{9}{*}{ 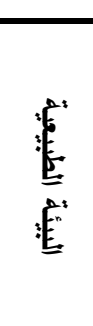 } \\
\hline 0.273 & 0.70 & 2.56 & 11.11 & 3 & 22.22 & 6 & 66.67 & 18 & $\mathrm{X} 1$ & \\
\hline 0.265 & 0.61 & 2.30 & 18.52 & 5 & 33.33 & 9 & 48.15 & 13 & $\mathrm{X} 2$ & \\
\hline 0.318 & 0.59 & 1.85 & 40.74 & 11 & 33.33 & 9 & 25.93 & 7 & $\mathrm{X} 3$ & \\
\hline 0.273 & 0.70 & 2.56 & 7.41 & 2 & 29.63 & 8 & 62.96 & 17 & $\mathrm{X} 4$ & \\
\hline 0.291 & 0.83 & 2.85 & 3.70 & 1 & 7.41 & 2 & 88.89 & 24 & $\mathrm{X} 5$ & \\
\hline 0.273 & 0.70 & 2.56 & 11.11 & 3 & 22.22 & 6 & 66.67 & 18 & X6 & \\
\hline 0.274 & 0.59 & 2.15 & 18.52 & 5 & 48.15 & 13 & 33.33 & 9 & $\mathrm{X} 7$ & \\
\hline 0.279 & 0.94 & 3.36 & \multicolumn{2}{|c|}{15.87} & \multicolumn{2}{|c|}{28.04} & 56.08 & & المؤشر الكلي & \\
\hline
\end{tabular}




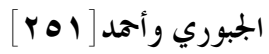

تشير معطيات الجدول ه وبالاستتاد للمؤشر الكلي لكل فئة الزبائن إلى وجود اتفاق

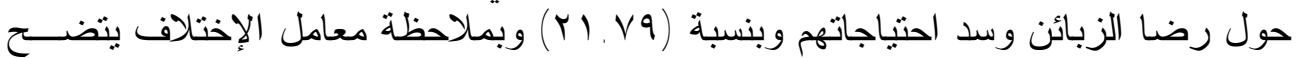

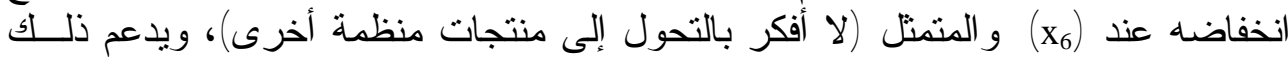

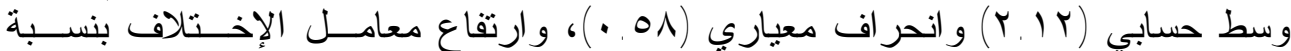

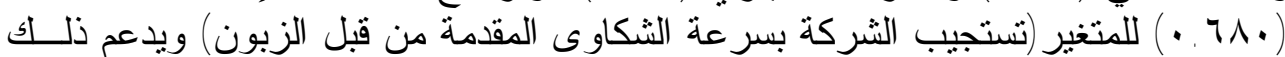

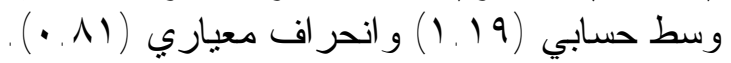

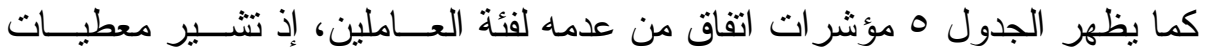

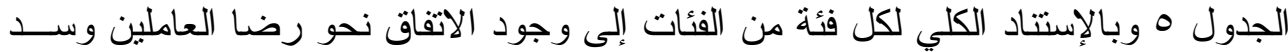

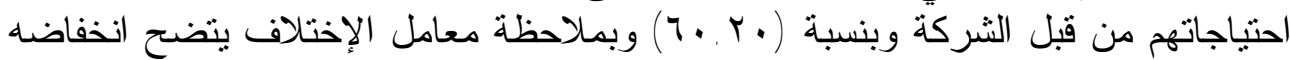

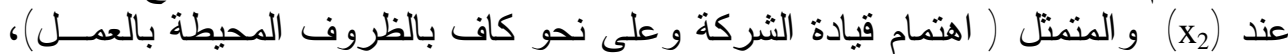

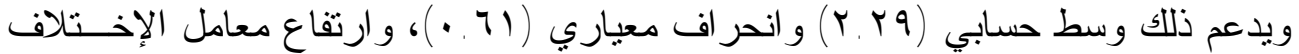

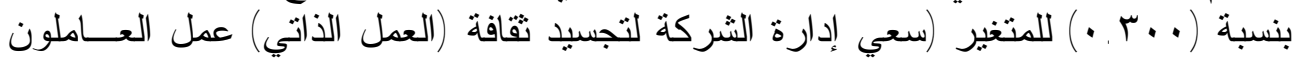

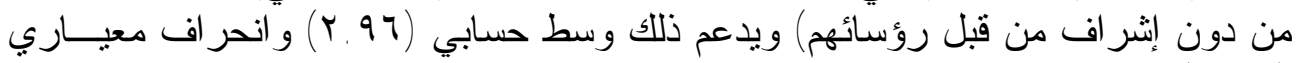
.$(\cdot 19)$

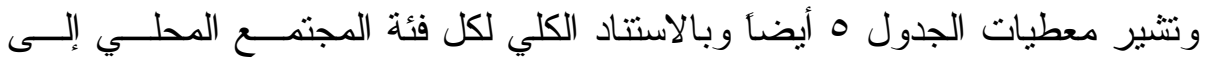

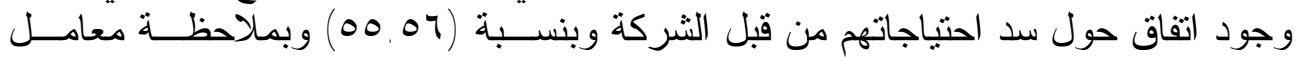

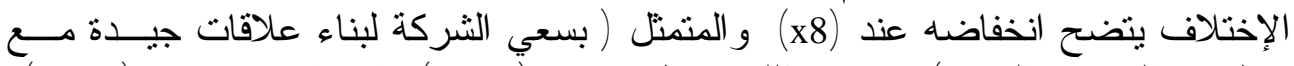

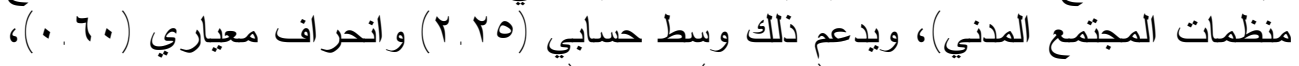

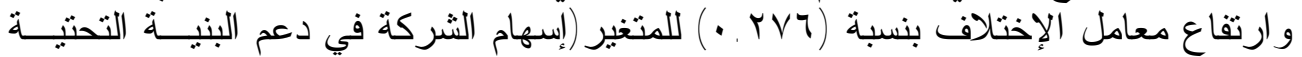

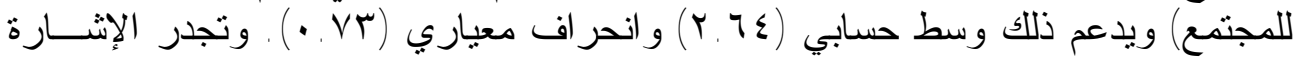

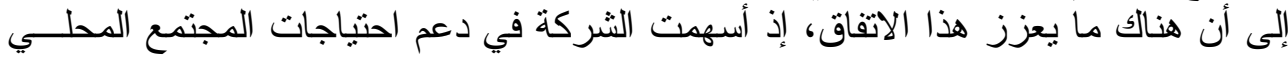

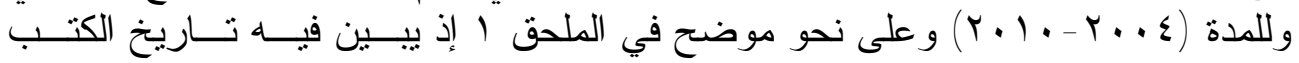
و الجهات الممنوحة لها الدعم ومقدار ذلك الدعم من مما يوفر قناعة تامة على دعــم إدارة الثركة للمجتمع المحلي.

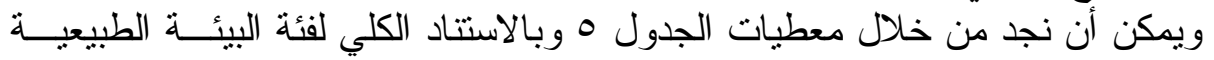

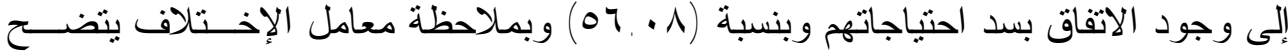

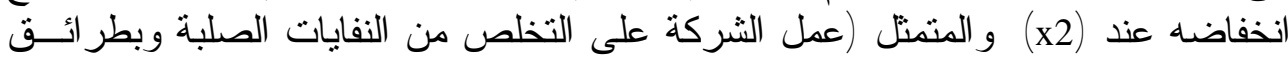

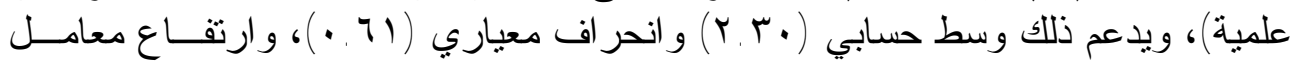

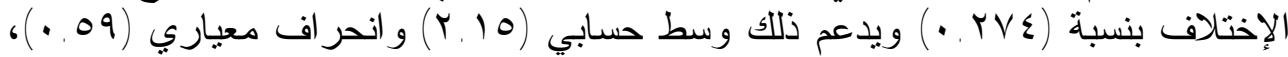

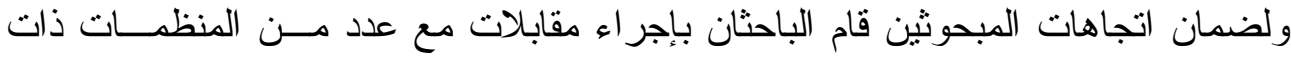

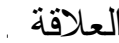

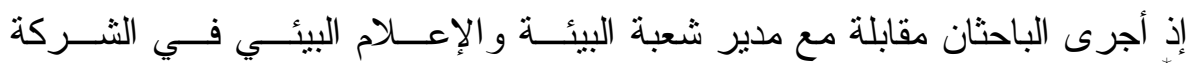

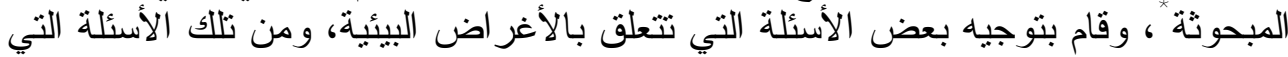

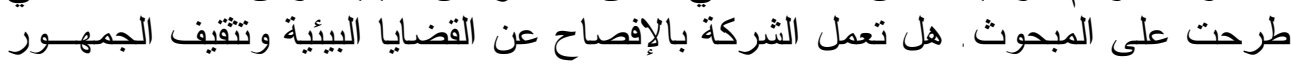
عليها؟

" الأستاذ عماد محمود عبداله مدير شعبة البيئة و الإعلام البيئي في الثـــركة العامـــة لصــــاعة الأدويـــة

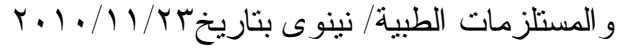


و أنثار المبحوث نعم للثركة ندوات تثقيفية ومؤتمر ات علمية حول القضـــايا البيأـــة

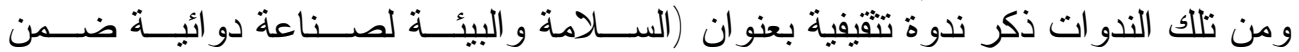

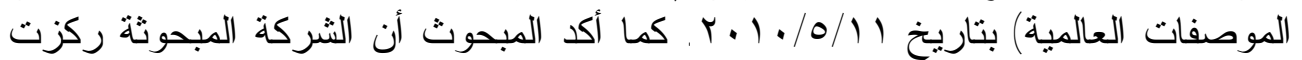

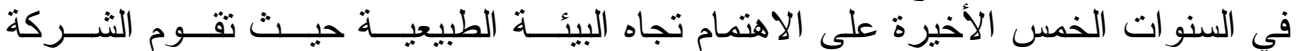

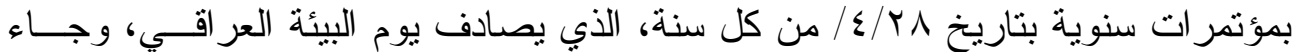

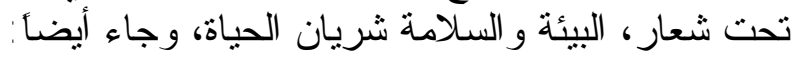

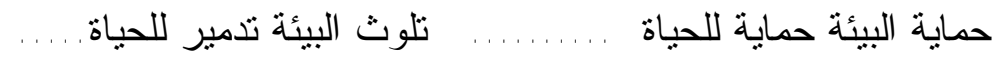

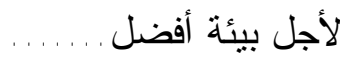
و أيضاً جاء في شعار

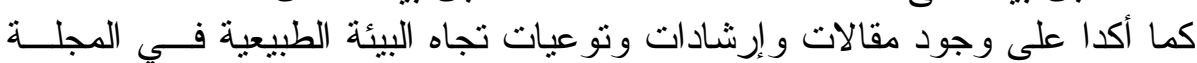
الثهرية التي تصدر من الثركة التردي

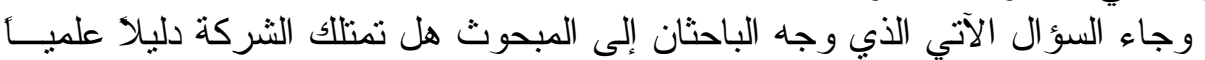

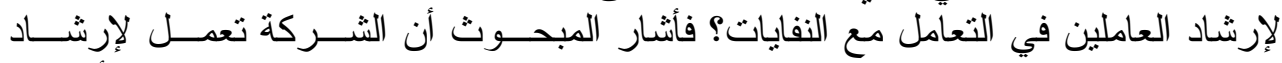

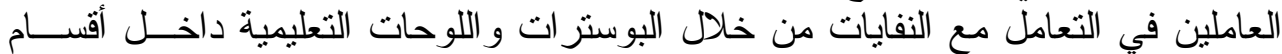

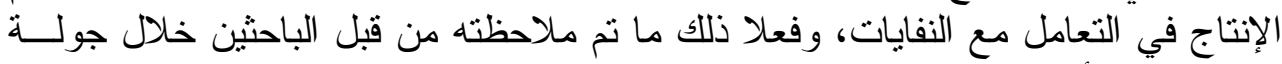
قام بها داخل أقسام الإنتاج.

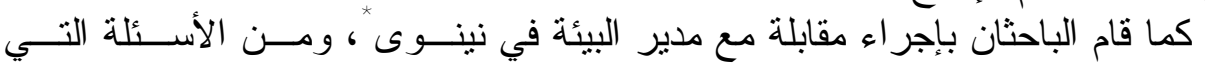

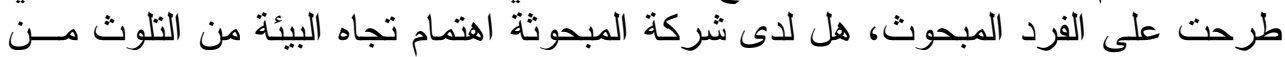

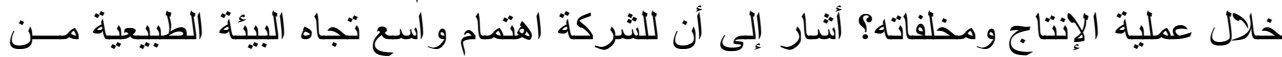

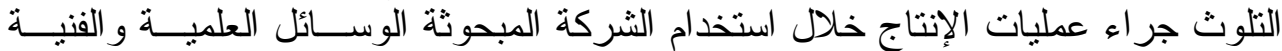

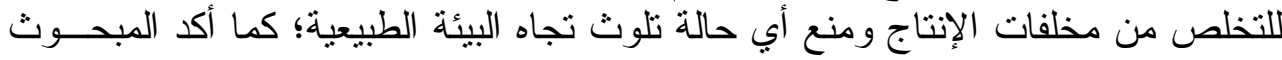

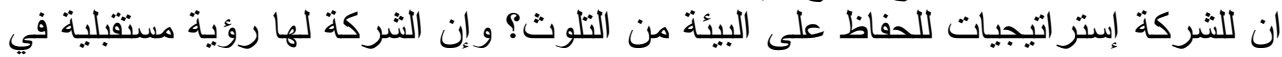

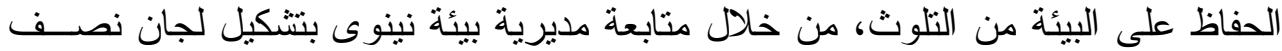

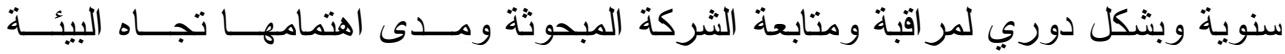

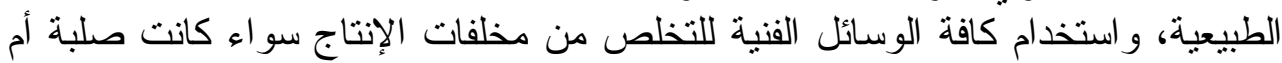
سائلة أم انبعاثات غازية التي تضر بالبياتئة الطبيعية.

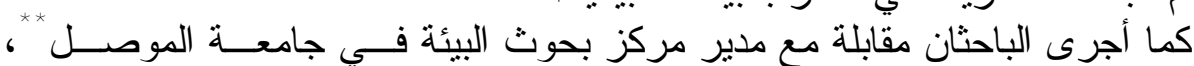

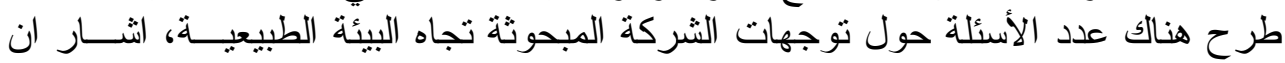

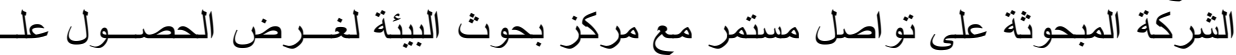

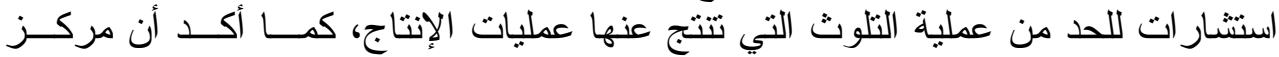

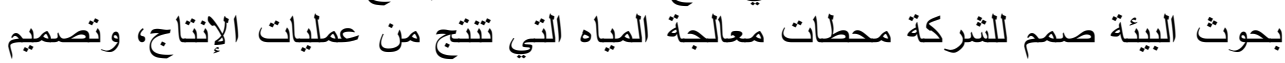

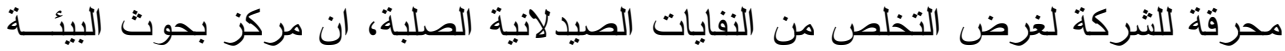

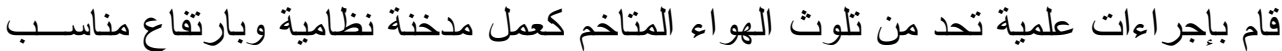

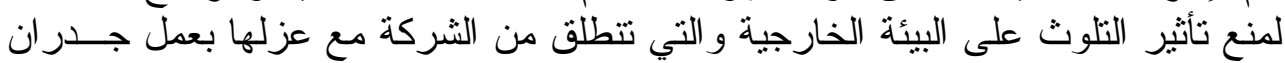

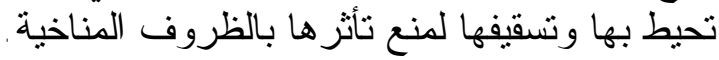


الجبوري وأمد[بror]

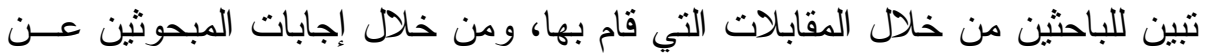

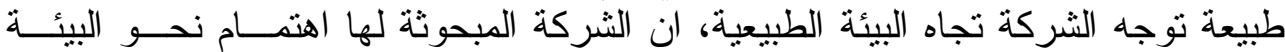
الطبيعية والحفاظ عليها من التلوث ولئل وبكافة الوسائل المتاحة.

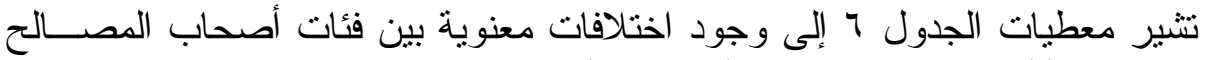

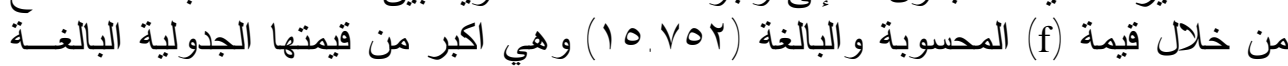

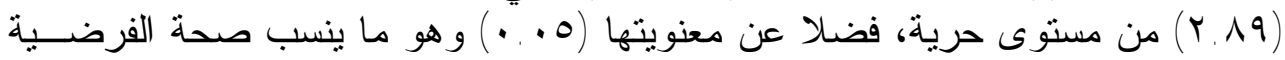

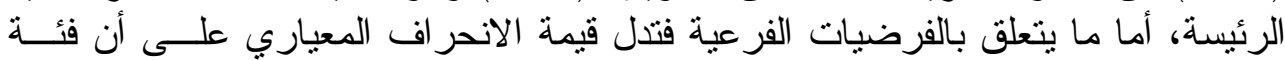

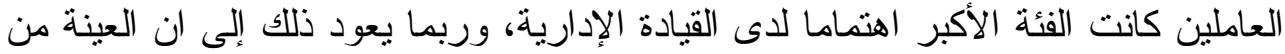

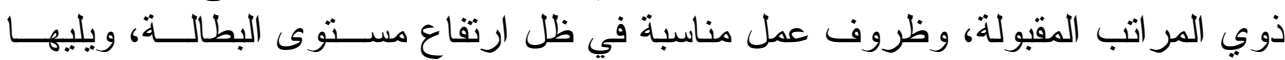

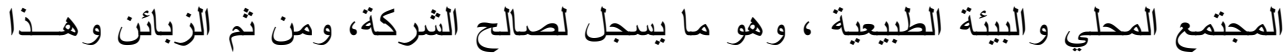

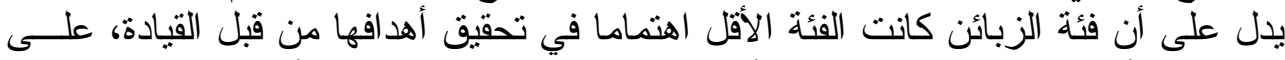

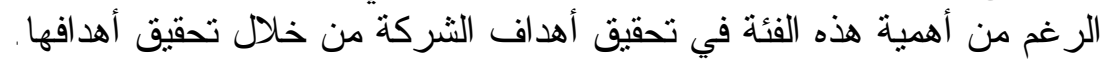

الاستتتاجات و المقترحات

أولاً - الاستنتاجات الاجنات

بعد الانتهاء من البحث نؤشر مجموعة من الاستتناجات الات على النحو الآتي:

1. . هناك اختلاف في تحديد فئات أصحاب المصالح ومرد ذلك إلى نشاط المنظمة ، فضلا

عن البيئة التي تعمل فيها.

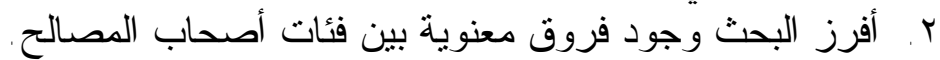

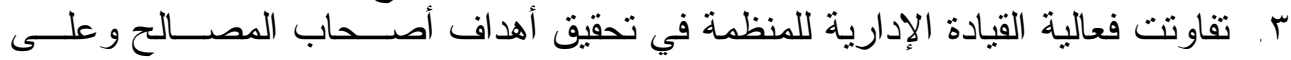

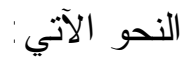

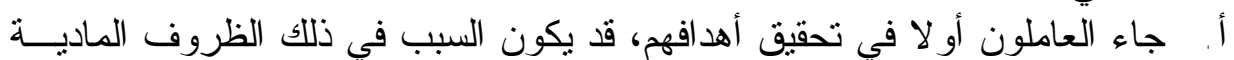

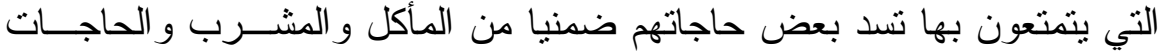

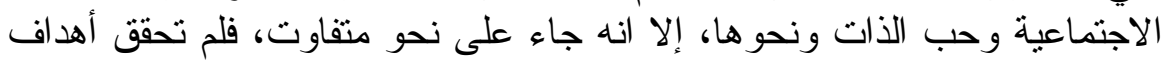

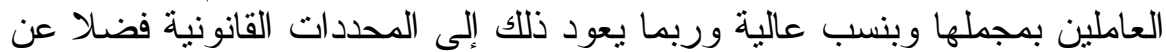

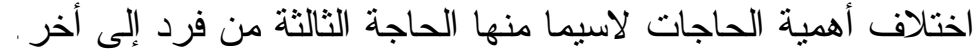

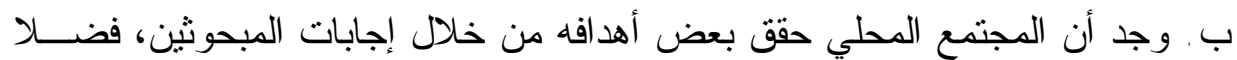
عن وثائق أكدت ذلك، ويعود ذللك إلى أن المنظمة تحملت مسؤوليتها الاجتماعية،

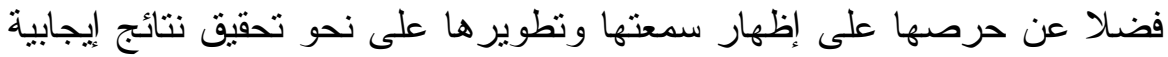
في المستقبل .

ت. وجد هنالك اهتمام بالبيئة من قبل المنظمة على الرغم من انخفاض مقبوليتهــا إلا لإن

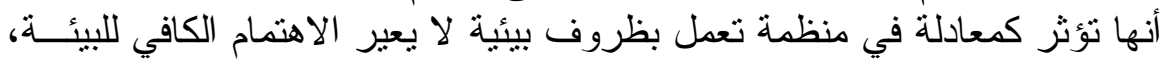

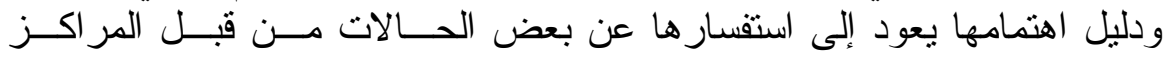

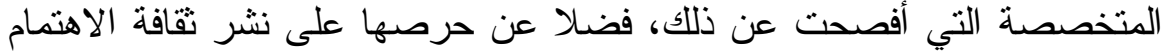

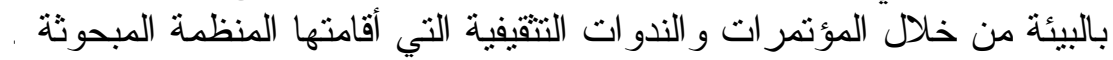

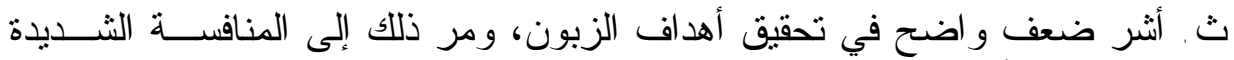

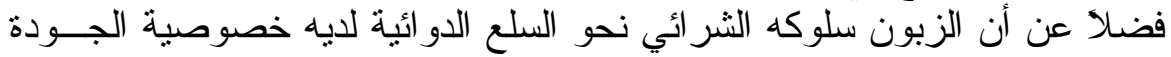

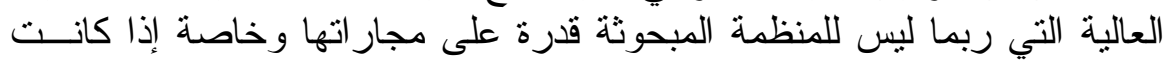




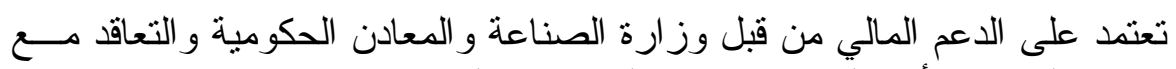

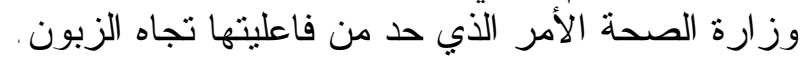

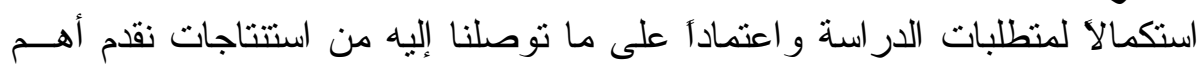

\section{ثانياً - المقترحات}

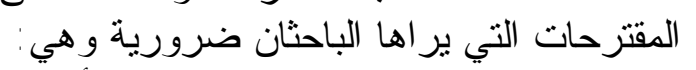

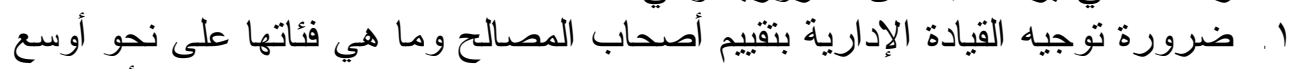

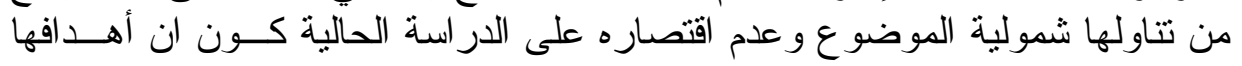

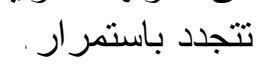

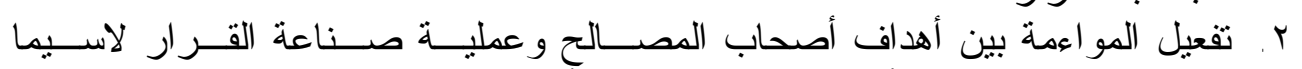

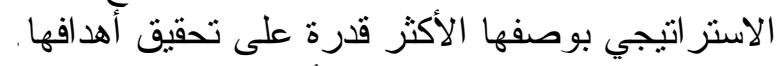

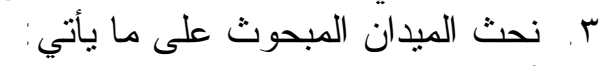

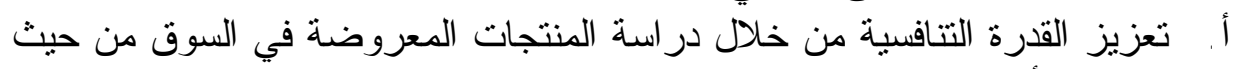

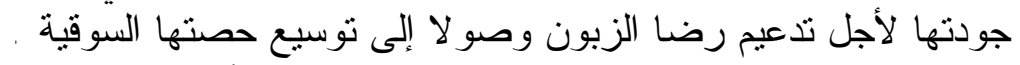

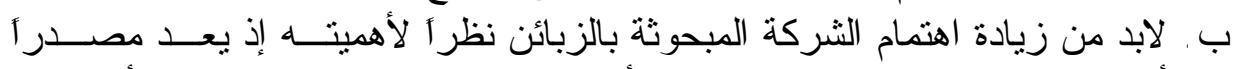

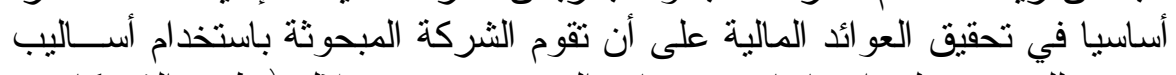

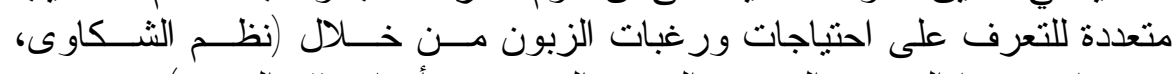

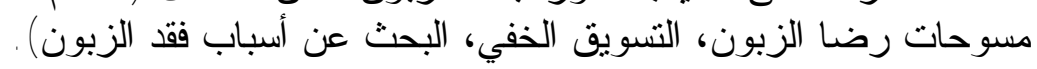

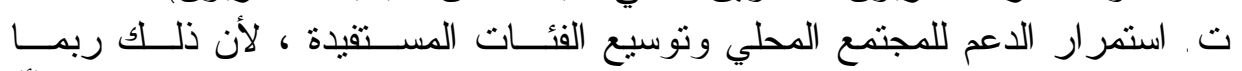

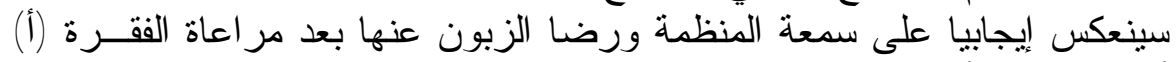

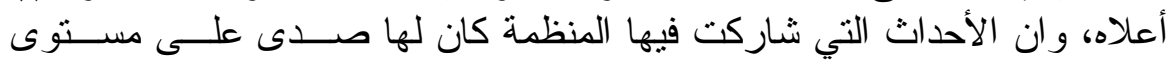

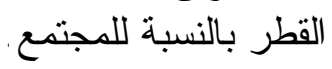

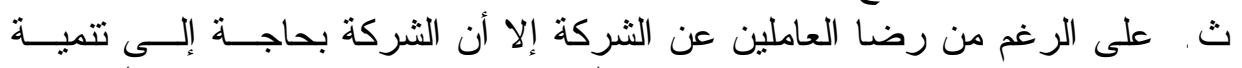

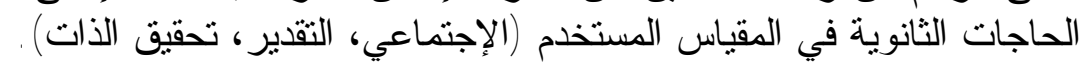

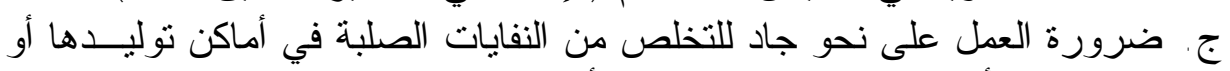

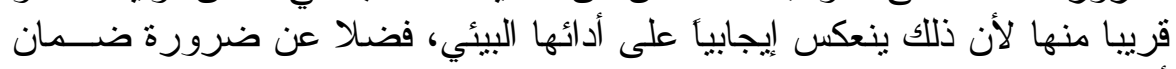

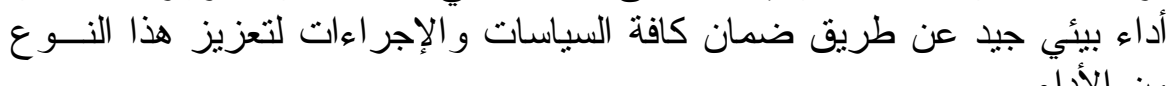
من الأداء.

\section{المراجع \\ أولاً - المراجع باللغة العربية}

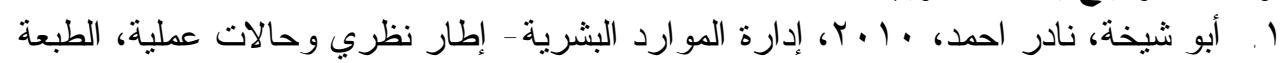

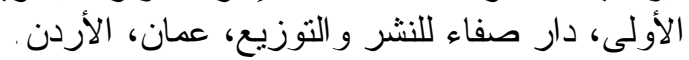

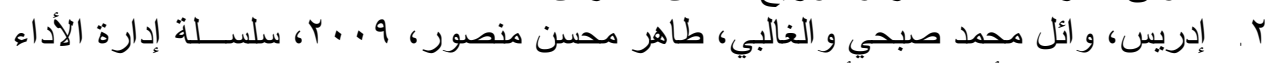

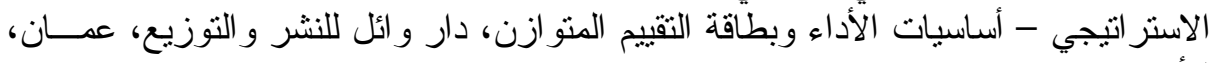
الأردن.

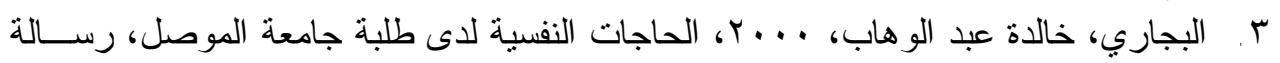

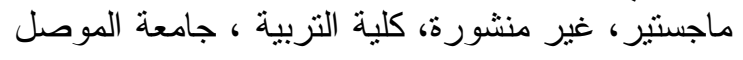




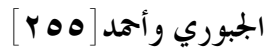

ع. . البكري، ثامر ياسر ، ع . . ؟، إدارة المعرفة التسويقية باعتماد إستر اتيجية العلاقة مع الزبون،

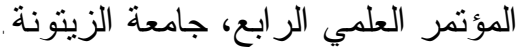

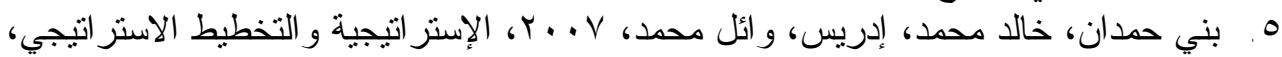

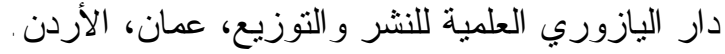

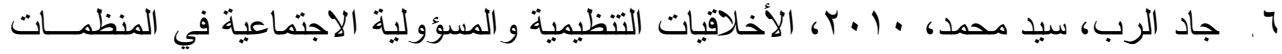

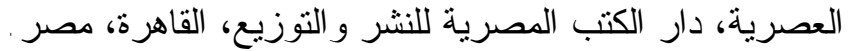

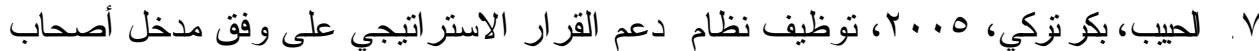

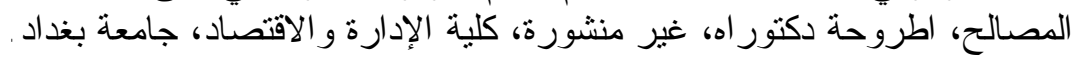

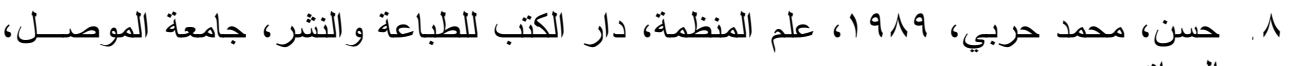

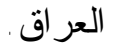

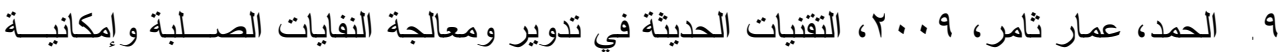

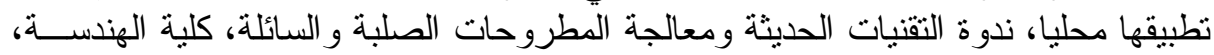

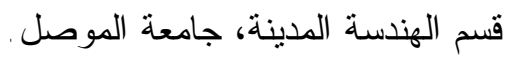

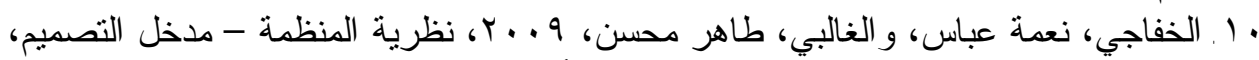

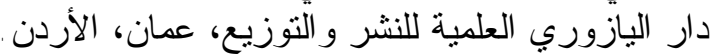

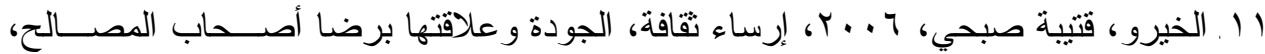

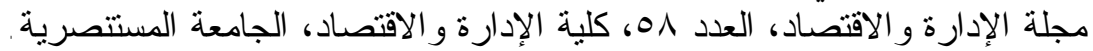

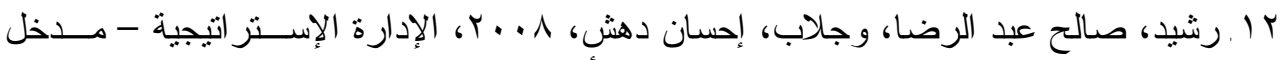

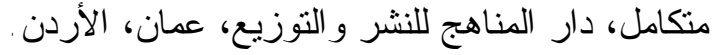

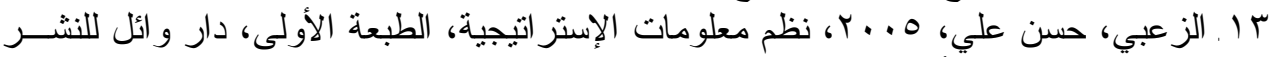

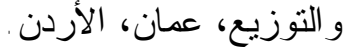

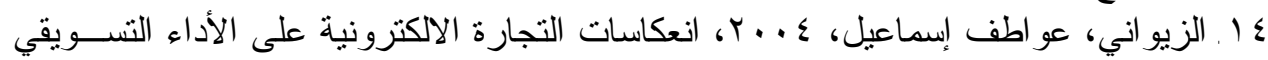

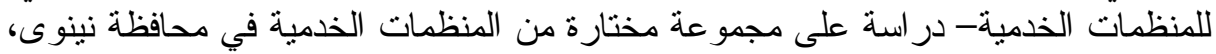

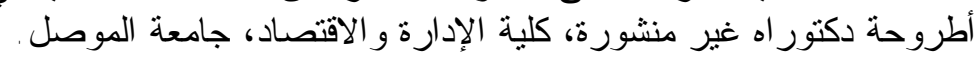

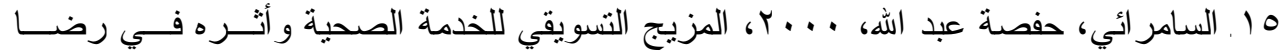

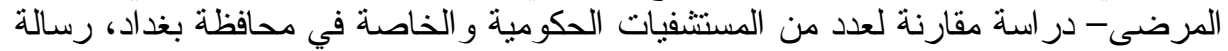

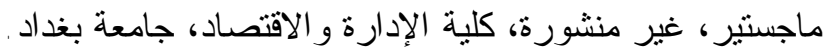

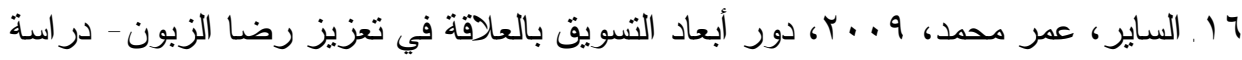

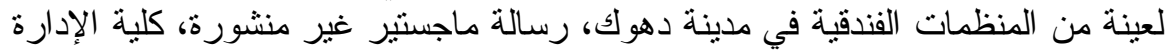

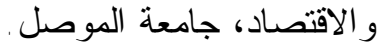

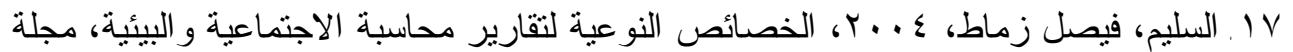

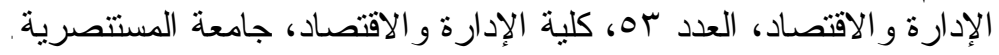

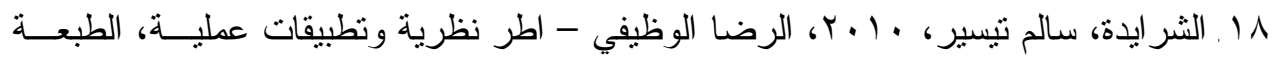

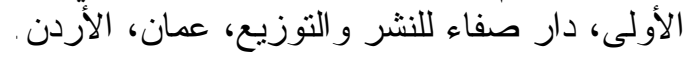

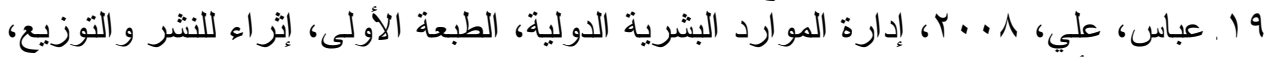

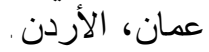

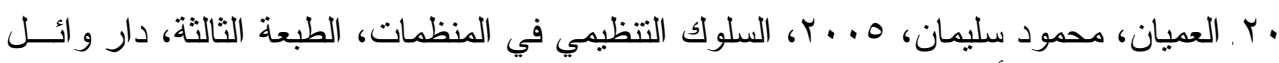

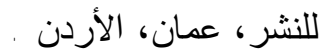

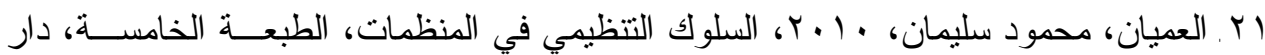

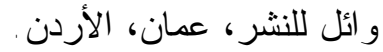




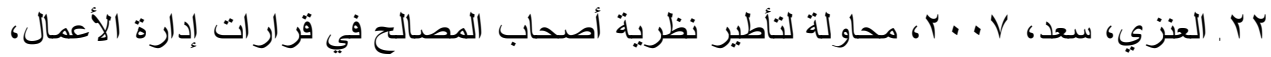

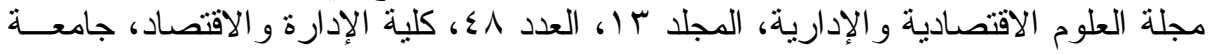
بغداد.

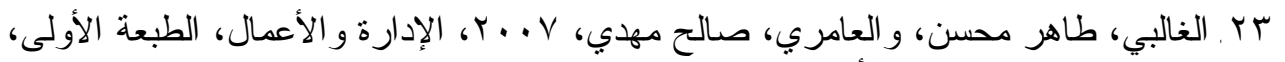

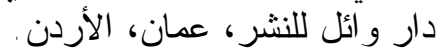

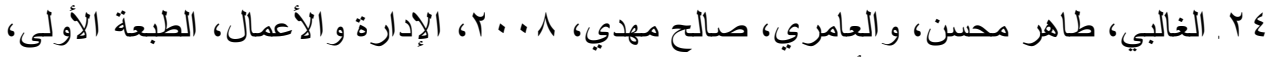

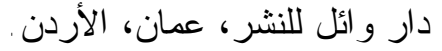

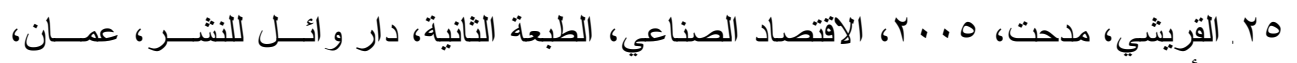

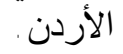

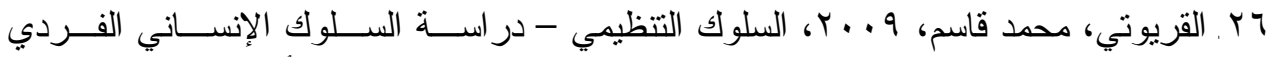

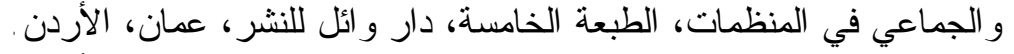

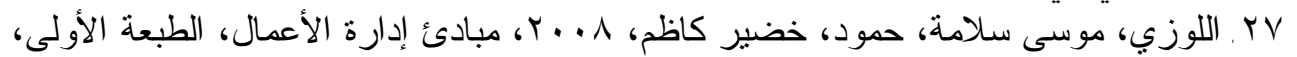

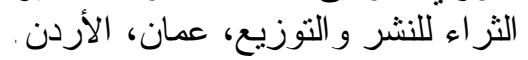

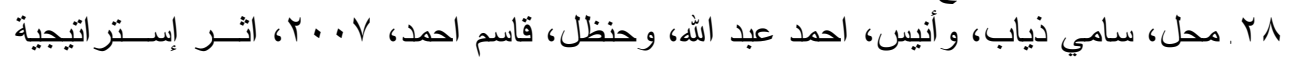

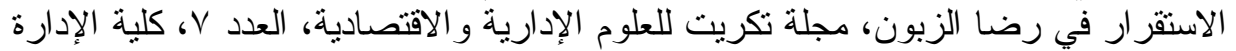

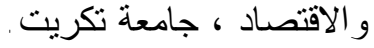

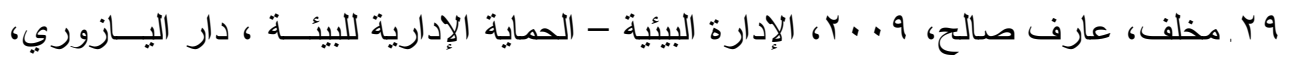
للنشر و التوزيع، عمان، الأردن، مان.

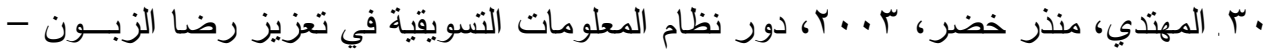

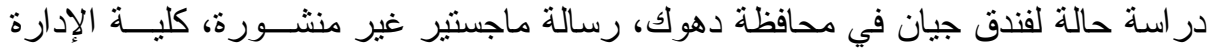

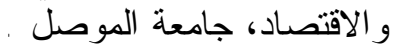

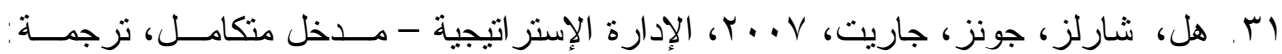

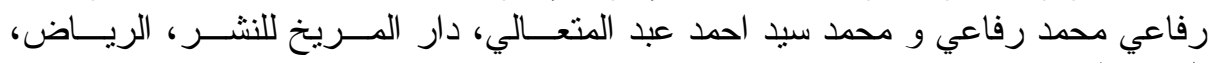

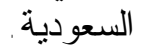

\section{ثاتياً - المراجع باللغة الأجنبية}

1. Ambler, Tim, 2000, Marketing metrics, BSR, Vol. 11, Issue London Business school.

2. Elias, Arun and Robert Cavana,2000, Stakeholder Analysis for Systems_Thinking and Modeling, new Zealand, http://www.mcs.vuw.ac. nz /opre/ornsnz /papers/BobCavana.pdf.

3. Freeman, Edward ,1984, Strategic Management: A Stakeholder Approach, Bitman, Boston,.

4. Hellviegcl, Don, Siocum, Jannw, Weed man, Bichavdw. 2001, Organization Behavior, south- Western college Publishing, Ohio, USA- Thomson cearning.

5. Johes, Gareth, 2001, Organizational Theory text and cases, Published by AddisehWesley, INC, USA.

6. Kotler, P, 2006, Marketing Management, $9^{\text {th }}$ ed. Printice- Hell, INC New Jersey.

7. Kotler, P, 2000, Marketing management, The Millennium Edition Englerod criffs NJ: prentice-Hall international.

8. Nath, Asou, Jerry A, 2000, Basic Environment Technology, $3^{\text {rd }}$ ed. Printing Hall New Jersey.

9. Setphen P. Robins,1978, personnel: The Management of Human Resource, Englewood cliffs, New Jersey prentice - Hell, Inc.,.

10. Thomson, Leign 2000, Marketing the team, New Jersey, prentice Hell. 